This manuscript was published as:

Jiskra, M.; Wiederhold, J. G.; Skyllberg, U.; Kronberg, R. M.; Kretzschmar, R., Source tracing of natural organic matter bound mercury in boreal forest runoff with mercury stable isotopes. Environ Sci Process Impacts 2017, 19, (10), 1235-1248.

Link to paper:

https://pubs.rsc.org/en/content/articlelanding/2017/em/c7em00245a\#!divAbstract

\title{
Source tracing of natural organic matter bound mercury in boreal forest runoff with mercury stable isotopes
}

July 29,2017

6 Martin Jiskra*,1,2,3, Jan G. Wiederhold ${ }^{*, 1,2,4}$, Ulf Skyllberg ${ }^{5}$, Rose-Marie Kronberg ${ }^{5}$, and Ruben Kretzschmar ${ }^{1}$

${ }^{1}$ Soil Chemistry, Institute of Biogeochemistry and Pollutant Dynamics (IBP),

9 ETH Zurich, CHN, CH-8092 Zurich, Switzerland

${ }^{2}$ Isotope Geochemistry, Institute of Geochemistry and Petrology (IGP), ETH Zurich, CH-8092 Zurich, Switzerland

${ }_{12}^{3}$ Observatoire Midi-Pyrénées, Laboratoire Géosciences Environnement Toulouse (GET), CNRS-IRD-Université de Toulouse, F-31400 Toulouse, France

${ }^{4}$ Department of Environmental Geosciences, University of Vienna, A-1090

15 Vienna, Austria

${ }^{5}$ Department of Forest Ecology and Management, Swedish University of Agricultural Sciences, S-90183 Umeå, Sweden

${ }_{18}$ *martin.jiskra@gmail.com, jan.wiederhold@univie.ac.at 


\section{Abstract}

${ }_{21}$ Terrestrial runoff represents a major source of mercury (Hg) to aquatic ecosystems. In boreal forest catchments, such as the one in northern Sweden studied here, mercury bound to natural organic matter (NOM) represents a

24 large fraction of mercury in the runoff. We present a method to measure $\mathrm{Hg}$ stable isotope signatures of colloidal Hg, mainly complexed by high molecular weight or colloidal natural organic matter (NOM) in natural waters based

27 on pre-enrichment by ultrafiltration, followed by freeze-drying and combustion. We report that $\mathrm{Hg}$ associated with high molecular weight NOM in the boreal forest runoff has very similar $\mathrm{Hg}$ isotope signatures as compared

so to the organic soil horizons of the catchment area. The mass-independent fractionation (MIF) signatures $\left(\Delta^{199} \mathrm{Hg}\right.$ and $\left.\Delta^{200} \mathrm{Hg}\right)$ measured in soils and runoff was in agreement with typical values reported for atmospheric gaseous

33 elemental mercury $\left(\mathrm{Hg}^{0}\right)$ and distinctly different from reported $\mathrm{Hg}$ isotope signatures in precipitation. We therefore suggest that most $\mathrm{Hg}$ in the boreal terrestrial ecosystem originated from the deposition of $\mathrm{Hg}^{0}$ through foliar

36 uptake rather than precipitation. Using a mixing model we calculated the contribution of soil horizons to the $\mathrm{Hg}$ in the runoff. At moderate to high flow runoff conditions, that prevailed during sampling, the uppermost part of the

39 organic horizon $(\mathrm{Oe} / \mathrm{He})$ contributed 50-70\% of the $\mathrm{Hg}$ in the runoff, while the underlying more humified organic $\mathrm{Oa} / \mathrm{Ha}$ and the mineral soil horizons displayed a lower mobility of $\mathrm{Hg}$. The good agreement of the $\mathrm{Hg}$ isotope re-

42 sults with other source tracing approaches using radiocarbon signatures and $\mathrm{Hg}$ : C ratios provides additional support for the strong coupling between $\mathrm{Hg}$ and NOM. The exploratory results from this study illustrate the potential

45 of $\mathrm{Hg}$ stable isotopes to trace the source of $\mathrm{Hg}$ from atmospheric deposition through the terrestrial ecosystem to soil runoff, and provide a basis for more in-depth studies investigating the mobility of $\mathrm{Hg}$ in terrestrial ecosystems

48 using $\mathrm{Hg}$ isotope signatures. 


\section{Introduction}

Humans are exposed to toxic methyl-mercury $(\mathrm{MeHg})$ primarily through the

${ }_{51}$ consumption of fish [1]. In Scandinavia, over $60 \%$ of all freshwater lakes contain fish with $\mathrm{Hg}$ concentrations exceeding the EU guideline for fish consumption [2]. Hg enters aquatic ecosystems by direct atmospheric deposi-

54 tion or via catchment runoff from terrestrial ecosystems [1]. The prediction of future $\mathrm{Hg}$ concentrations in the atmosphere, aquatic environments, and eventually in fish is essential for the assessment of future human $\mathrm{Hg}$ expo-

57 sure through fish consumption. Anthropogenic $\mathrm{Hg}$ emissions have led to a $20 \%$ increase in the soil $\mathrm{Hg}$ pool [3]. International efforts to reduce primary anthropogenic $\mathrm{Hg}$ emissions, agreed on by the Minamata Convention

60 on Mercury coordinated by the United Nations Environment Programme [4], will result in reduced atmospheric deposition. With the decrease in direct atmospheric $\mathrm{Hg}$ (II) deposition related to primary anthropogenic emissions, one

${ }_{63}$ can expect an increasing relative contribution of $\mathrm{Hg}$ from terrestrial runoff to aquatic ecosystems. Furthermore, increasing temperatures driven by climate change are expected to increase the export of natural organic matter

${ }_{66}$ (NOM) from boreal systems [5] and accordingly may result in higher $\mathrm{Hg}$ export associated with NOM. It is therefore essential to understand the $\mathrm{Hg}$ sources and input pathways from terrestrial ecosystems and how they re-

69 spond to changes in environmental conditions and atmospheric Hg deposition, in order to predict the development of $\mathrm{Hg}$ concentrations in aquatic ecosystems. Understanding the $\mathrm{Hg}$ transfer from boreal forests to aquatic

72 ecosystems is of special importance because the highest fish $\mathrm{Hg}$ concentrations in Sweden and Finland have been observed in regions of boreal coniferous forests [2]. $\mathrm{Hg}$ forms strong complexes with $\mathrm{NOM}[6]$, which has an

75 important role in controlling terrestrial $\mathrm{Hg}$ runoff, illustrated by a strong correlation between dissolved $\mathrm{Hg}$ concentrations and dissolved organic carbon concentrations.[2, 7, 8, 9, 10, 11]. A survey on natural freshwaters from

78 the USA by Babiarz et al. reported that a large fraction of the dissolved $\mathrm{Hg}$ $(<0.45 \mu \mathrm{m})$ is associated with high molecular weight NOM or other colloids $(>10 \mathrm{kDa})[12]$. A strong coupling of terrestrial $\mathrm{Hg}$ runoff to NOM was also 
described in studies using terrestrial organic matter biomarkers as tracers for the source of $\mathrm{Hg}$ in lake sediments $[13,14]$. MeHg from terrestrial sources was shown to exhibit a higher potential for bioaccumulation than $\mathrm{MeHg}$ in sediments [15]. Forest management practices were shown to affect both NOM and $\mathrm{Hg}$ export to aquatic ecosystems, e.g. through forest harvest (clear-cut), after which increased $\mathrm{Hg}$ concentrations in water, zooplankton, and fish have

87 been observed $[9,16,17,18,19,20]$. In two accompanying studies we reported that forest harvest lead to an enhanced $\mathrm{MeHg}$ formation in soils and an increased $\mathrm{MeHg}$ transport from the same study sites [21, 22].

90 The analysis of natural $\mathrm{Hg}$ stable isotope signatures provides a promising tool to trace sources and transformations of $\mathrm{Hg}$ in the environment $[23,24]$. Atmospheric gaseous elemental mercury $\left(\mathrm{Hg}^{0}\right)$ and oxidized $\mathrm{Hg}(\mathrm{II})$ in pre-

93 cipitation, the two main atmospheric mercury sources for terrestrial ecosystems, are characterized by distinct mass-independent $\mathrm{Hg}$ isotope anomalies $[25,26,27,28,29,30,31,32]$. Using the isotopic fingerprints of $\mathrm{Hg}^{0}$ and 96 $\mathrm{Hg}(\mathrm{II})$ in precipitation recent studies could show that 60-90\% of $\mathrm{Hg}$ found in soils originated from the direct deposition of $\mathrm{Hg}^{0}$ through uptake by plants and subsequent litterfall [29, 31, 32, 33, 34]. These findings are in contrast

99 to previous concepts that oxidized $\mathrm{Hg}$ (II) in precipitation is the dominant pathway of atmospheric $\mathrm{Hg}$ deposition [1, 35]. In aquatic ecosystems, $\mathrm{Hg}$ stable isotope analysis has been successfully applied to trace $\mathrm{Hg}$ sources in

102 fish [36, 37, 38, 39], e.g., by relating the $\mathrm{Hg}$ isotope signature of fish to the signatures of sediments and thereby inferring the contribution of anthropogenic pollution in fish [37] or the role of sediments as food source [38]. Furthermore,

$105 \mathrm{Hg}$ stable isotopes were used to elucidate differences in $\mathrm{MeHg}$ sources between terrestrial and aquatic organisms [40, 41, 42]. To fully understand processes governing $\mathrm{Hg}$ transformations and uptake into organisms using $\mathrm{Hg}$ stable 108 isotopes it is essential to know the isotopic signature of the $\mathrm{Hg}$ source [42]. Direct measurements of $\mathrm{Hg}$ stable isotope signatures in surface water, the link between the source of $\mathrm{Hg}$ and the aquatic organisms, however are limited to 111 few studies $[43,44]$. Only recently, analytical techniques have been developed for the measurement of stable $\mathrm{Hg}$ isotopes in natural water samples, based on acid digestion and pre-enrichment on an ion-exchange column [44, 45, 46] 
114 or stannous chloride reduction and purge and trap [25, 31, 32, 47, 48]. So far aqueous $\mathrm{Hg}$ isotope data have been mainly reported for precipitation samples (rain and snow) $[25,26,27,28,29,47]$ exhibiting low NOM concentrations.

Here, we developed an alternative method based on an ultrafiltration technique used for pre-enrichment, suitable for water samples with high NOM concentrations $(>10 \mathrm{mg} / \mathrm{L})$ combined with a two-step oven combustion system. This approach may prove useful in many natural aquatic environments, because the transport of $\mathrm{Hg}$ is closely linked to NOM and many important $\mathrm{Hg}$ transformation processes (e.g., methylation, demethylation, reduction) ${ }_{123}$ occur in NOM-rich environments. In this exploratory study we investigated $\mathrm{Hg}$ stable isotope signatures of NOM-bound $\mathrm{Hg}$ in a boreal forest catchment runoff in northern Sweden and compared it to signatures of different soil 126 horizons, some of them already published previously [33]. The study had the following objectives: (i) to develop and validate a pre-enrichment method for the measurement of $\mathrm{Hg}$ isotope signatures in water samples with high NOM concentrations, (ii) to investigate if the isotopic signature of catchment runofff is fractionated with respect to the $\mathrm{Hg}$ pools in soils, (iii) to trace the source of $\mathrm{Hg}$ in boreal catchment runoff back to soil horizons and 132 atmospheric deposition pathways.

\section{Experimental section}

\subsection{Materials and reagents}

135 Polyethylene canisters $(25 \mathrm{~L})$ were cleaned in the laboratory with $0.24 \mathrm{M}$ $\mathrm{HCl} / 0.32 \mathrm{M} \mathrm{HNO}_{3}(2 \times)$ and ultrapure water $(>18 \mathrm{M} \Omega \mathrm{cm}, 3 \times)$ and rinsed with sample water in the field $(3 \times)$. All filtration steps were performed with a peristaltic pump (Masterflex I/P, Cole-Parmer) equipped with spallation-free pump-tubing (GORE Style 100SC, Cole-Parmer). All tubing, manometer, valves and fittings were made of Teflon to minimize $\mathrm{Hg}$ and NOM sorption.

${ }_{141} \quad 0.45 \mu \mathrm{m}$ cross-flow filtration was performed with a $142 \mathrm{~mm}$ mixed cellulose ester membrane (HAWP14250, Merck Millipore) on a self-constructed Teflon filter-holder. For ultrafiltration, a hollow-fiber system was used (1 kDa cut- 
off, Polysulfone, UFP-1-C-9, GE Life Sciences). The filtration system was cleaned by circulating $0.05 \mathrm{M}$ citric acid ( $\mathrm{pH} 2-2.5)$ and $\mathrm{NaOH}(0.1 \mathrm{M})$ for 0.5 $\mathrm{h}$ each, to remove iron precipitates and organic matter, respectively, followed ${ }_{147}$ by repeated flushing with ultrapure water.

\section{$2.2 \quad$ Study area}

Samples were taken from four small catchments (5-30 ha) of boreal forests 150 in northern Sweden close to Junsele (Figure SI S3.1, coordinates: $63^{\circ} 50^{\prime} \mathrm{N}$, $17^{\circ} 00^{\prime} \mathrm{E}$ ), each drained by a first-order stream. Two sites (reference site 1 and 2) were covered by mature (>80-years-old) Norway spruce (Picea abies) 153 forest stands. At two sites (clear-cut site 1 and 2) with similar mature stands, trees were harvested two years before and planted with Norway spruce one year prior to the sampling. All soils were classified as either Podzols or His-

156 tosols [49] and have been actively drained by ditches dug in the early 1900's to increase forest productivity. Soil profiles were sampled in July 2011 at 5 locations along a transect perpendicular to the first-order stream, as de159 scribed previously by Jiskra et al. [33]. The distance from the soil profiles to the stream was between 1 and $72 \mathrm{~m}$ (SI Table S1 and S2), covering the riparian zone and lower sections of the hillslopes representing the transition between discharge areas and upland prior to forest harvest (reference site 1 and 2) and new discharge areas created after harvest (clear-cut site 1 and 2). Composite samples consisting of 5 soil samples taken within approximately $10 \mathrm{~m}^{2}$ were divided into surface organic horizons (Oe/He), underlying $\mathrm{Oa} / \mathrm{Ha}$ organic horizons exhibiting a higher degree of humification, and for Podzols mineral E+B horizons. Of the $\mathrm{Ha}$ and $\mathrm{B}$ horizons only the top 15 and $5 \mathrm{~cm}$ were sampled, respectively. Soil Hg isotope signatures of the harvested sites (clear-cut site 1 and 2) are presented for the first time in this publication. Soil $\mathrm{Hg}$ isotope signatures from reference site 1 and 2 have been reported 171 previously [33]. Water samples from the first-order streams in the runoff of the four boreal forest catchments were collected in September 2012 for $\mathrm{Hg}$ isotope and radiocarbon analysis. In addition to the first-order streams, a 174 larger stream draining all of the four catchments (Lillsele stream) and the 
inlet and outlet of a nearby lake (Västra Kortingvattnet, VK) were sampled (Figure S1). Water samples for total $\mathrm{Hg}$ and dissolved organic carbon (DOC) analysis were taken at 9 occasions during 2011 and 2012 (Figure S2) [21]. Reference sites 1 and 2 correspond to the REF1 and REF2 above the postglacial marine limit (ML), and the clear-cut site 1 and 2 correspond to CC2 and CC3 above ML in the studies of Kronberg et al. [21][22].

\subsection{Soil sample preparation}

The soil sampling and oven combustion procedure has been described previously by Jiskra et al. [33]. In short, composite samples were homogenized using a $4 \mathrm{~mm}$ cutting sieve, dried in an oven at $45{ }^{\circ} \mathrm{C}$ and further homogenized using a rotary disk mill. The sample powder was used for elemental concentrations, Hg isotope, and radiocarbon analyses. For Hg isotope analysis, the samples were combusted in a two-stage combustion oven connected to an oxidizing liquid trap, as previously described [33].

\subsection{Water sample preparation}

We developed a sample enrichment procedure for $\mathrm{Hg}$ associated with high molecular weight NOM and colloids (size range: $1 \mathrm{kDa}$ to $0.45 \mu \mathrm{m}$ ) based on pre-enrichment by ultrafiltration. For aqueous samples with high NOM concentrations (13.7 to $58.5 \mathrm{mg} \mathrm{L}^{-1}$ ) with background concentrations of $\mathrm{Hg}$ (3.9 to $14.0 \mathrm{ng} \mathrm{L}^{-1}$ ) and low sulfide concentrations (below detection limit to $1950.2 \mu \mathrm{M}$ ) as found in boreal forest runoff of this study [21, 22], $\mathrm{Hg}$ (II) is mainly complexed to thiol (SH) groups of NOM $[6,50,51]$. Some $\mathrm{Hg}(\mathrm{II})$, in particular from the clear-cut sites exhibiting more reducing conditions[21, 22] might also be present in the form of $\mathrm{Hg}$-sulfide nanoparticles coated with NOM [52]. A large fraction of the $\mathrm{Hg}$ (II) is associated with high molecular weight NOM or other colloids $(>1 \mathrm{kDa})[12]$ and therefore ultrafiltration allows for an enrichment of $\mathrm{Hg}$, together with the $>1 \mathrm{kDa}$ fraction in the retentate.

A scheme of the pre-enrichment steps is given in Figure 1. $50 \mathrm{~L}$ of water per sample were transported to the laboratory on the day of sampling 204 and refrigerated at $4{ }^{\circ} \mathrm{C}$ (step 1, Figure 1) until filtration was performed. 
Samples were filtered within $24 \mathrm{~h}$ using a $0.45 \mu \mathrm{m}$ cutoff crossfiltration membrane to remove particulate matter and bacteria (step 2, Figure 1). Water samples were then circulated over the tangential flow ultrafiltration system, with water, dissolved ions, and low molecular weight NOM passing through the cutoff $(<1 \mathrm{kDa})$ of the ultrafiltration membrane (permeate). Over time $(\approx 6 \mathrm{~h})$ this led to an enrichment of colloids, mainly characterized by higher molecular weight NOM $(>1 \mathrm{kDa})$ and concomitantly $\mathrm{Hg}$ in the remaining fraction (retentate, $>1 \mathrm{kDa},<0.45 \mu \mathrm{m}$ ) (step 3, Figure 1). For the Swedish runoff samples in our study, this process allowed an enrichment of on average $38 \%( \pm 10 \%)$ of the total dissolved $(<0.45 \mu \mathrm{m}) \mathrm{Hg}$ in the $\approx 1 \mathrm{~L}$ retentate sample, resulting in an enrichment factor $\left(\mathrm{C}(\mathrm{Hg})_{\text {retentate }} /\left(\mathrm{C}(\mathrm{Hg})_{\text {feedsolution }}\right)\right.$ of $\approx 20$ compared to the initial $\mathrm{Hg}$ concentration (ESI Table S7). The $\approx 1 \mathrm{~L}$ retentate used for $\mathrm{Hg}$ isotope analysis was frozen and the remaining water was removed by freeze-drying (ALPHA 2-4 LDplus, Christ) (step 4, Figure 1). Finally the freeze-dried organic carbon was combusted in the two-stage oven system and total $\mathrm{Hg}$ trapped in an oxidizing liquid trap (step 5, Figure 1), as previously described for soil samples by Jiskra et al. [33].

During tangential-flow ultrafiltration, the concentration of NOM in the permeate is not only dependent on the membrane cutoff, but also on the NOM concentration in the retentate. Furthermore, membrane fouling occurs over time. Therefore, the fraction of NOM recovered in the retentate depends on the number of cycles the retentate has passed over the membrane. It is important to note that this decrease of the NOM fraction in the retentate with cycle number is associated with the physical performance of the ultrafiltration process and does not imply any change of the molecular structure of the NOM or the speciation of $\mathrm{Hg}$. Therefore the $\mathrm{Hg}$ fractions in the retentate 231 were highest in the study by Babiarz et al. [12] (5 L feed volume), followed by the SM validation samples (10 L feed volume) and the Swedish runoff samples (50 L feed volume). It is important to note that the $\mathrm{Hg}$ fraction in 234 the $<0.45 \mu \mathrm{m}$ to $>1 \mathrm{kDa}$ retentate has to be understood as the ultrafiltration method yield and not as a quantification approach of the size fraction between $<0.45 \mu \mathrm{m}$ and $>1 \mathrm{kDa}$ in the natural sample. We therefore suggest that the physical enrichment based on molecular size of the NOM did not 
introduce any methodological artifacts on the $\mathrm{Hg}$ isotope composition, even though only a part of the total $\mathrm{Hg}$ in the system was enriched together with the higher molecular weight NOM.

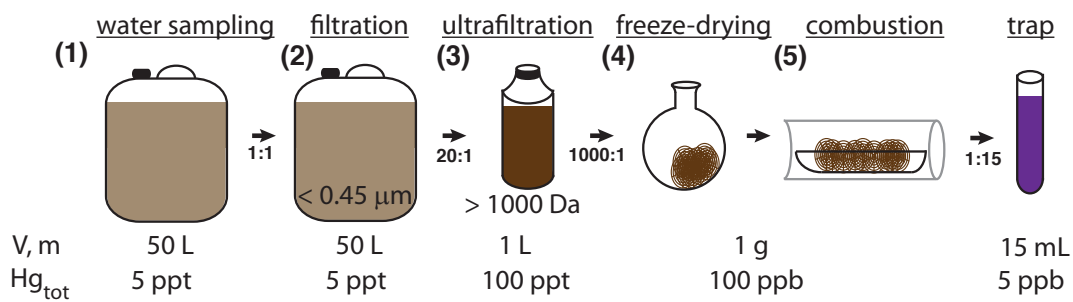

Figure 1: Schematic overview for the enrichment of $\mathrm{Hg}$ in water with high $\mathrm{NOM}$ concentration for $\mathrm{Hg}$ isotope analysis. Volumes (V) of water samples and mass $(\mathrm{m})$ of solid sample and typical total $\mathrm{Hg}$ concentrations $\left(\mathrm{Hg}_{\text {tot }}\right)$. The ratios represent typical enrichments in $\mathrm{Hg}$ concentration during ultrafiltration and freeze-drying and dilution during combustion.

To validate the enrichment method, water from a small lake in the peatland Seleger Moor (SM, Rifferswil, Switzerland) with high NOM concentra243 tions $\left(\approx 33 \mathrm{mg} \mathrm{L}^{-1}\right)$ and low $\mathrm{Hg}$ concentration $\left(<<10 \mathrm{ng} \mathrm{L}^{-1}\right)$ was collected. The SM validation samples $(10 \mathrm{~L})$ were filtered $(0.45 \mu \mathrm{m})$ and then spiked with 50, 100, and $250 \mathrm{ng} \mathrm{\textrm {L } ^ { - 1 }}$ of our inhouse $\mathrm{Hg}$ isotope standard (ETH${ }_{246}$ Fluka), conditioned for $24 \mathrm{~h}$, and processed as described above. During ultrafiltration (step 3, Figure 1$)$ the permeate fraction $(<1 \mathrm{kDa})$ and the retentate fraction $(<0.45 \mu \mathrm{m},>1 \mathrm{kDa})$ were collected separately in addition to 249 a fraction recovered from the ultrafiltration membrane by rinsing with $2 \mathrm{~L}$ ultrapure water (rinse).

\subsection{Analytical methods}

${ }_{252}$ Solutions of the oxidizing liquid trap, containing $1 \% \mathrm{KMnO}_{4}(\mathrm{w} / \mathrm{v})$ in $10 \% \mathrm{H}_{2} \mathrm{SO}_{4}(\mathrm{v} / \mathrm{v})$ were pre-reduced using $0.66 \%(\mathrm{w} / \mathrm{v})$ hydroxylaminehydrochloride $\left(\mathrm{NH}_{2} \mathrm{OH}-\mathrm{HCl}\right)$ and diluted to 5 or $2.5 \mathrm{ppb} \mathrm{Hg}$ for isotope mea-

255 surements. Hg isotope signatures were measured using cold vapor generation stannous chloride reduction (CV; HGX-200, Cetac) coupled to a multicollector inductively coupled plasma mass spectrometer (MC-ICPMS) as described 
${ }_{258}$ in detail previously $[33,53,54]$. Briefly, all $\mathrm{Hg}$ masses were measured simultaneously for 108 integration cycles of 5 sec. Measured Tl (NIST-997) masses 203 and 205, continuously introduced using a desolvating nebulizer (Apex,

${ }_{261}$ Elemental Scientific) were used for instrumental mass bias correction. $\mathrm{Hg}$ isotope signatures are reported relative to the bracketing standard (NIST3133) measured prior to and after each sample. Mass-dependent fractiona${ }_{264}$ tion (MDF) is reported as $\delta^{202} \mathrm{Hg}$ (eq: 1) and mass-independent fractionation (MIF) as $\Delta^{199} \mathrm{Hg}, \Delta^{200} \mathrm{Hg}, \Delta^{201} \mathrm{Hg}$, and $\Delta^{204} \mathrm{Hg}$ (eq: $2-5$ ) following previous recommendations of Blum and Bergquist [55] and Coplen [56].

$$
\begin{aligned}
& \delta^{202} \mathrm{Hg}=\frac{\left({ }^{202} \mathrm{Hg} /{ }^{198} \mathrm{Hg}\right)_{\text {sample }}}{\left({ }^{202} \mathrm{Hg} /{ }^{198} \mathrm{Hg}\right)_{\text {NIST }-3133}}-1 \\
& \Delta^{199} \mathrm{Hg}=\delta^{199} \mathrm{Hg}-\left(\delta^{202} \mathrm{Hg} \times 0.2520\right) \\
& \Delta^{200} \mathrm{Hg}=\delta^{200} \mathrm{Hg}-\left(\delta^{202} \mathrm{Hg} \times 0.5024\right) \\
& \Delta^{201} \mathrm{Hg}=\delta^{201} \mathrm{Hg}-\left(\delta^{202} \mathrm{Hg} \times 0.7520\right) \\
& \Delta^{204} \mathrm{Hg}=\delta^{204} \mathrm{Hg}-\left(\delta^{202} \mathrm{Hg} \times 1.493\right)
\end{aligned}
$$

267

The regularly measured in-house standard (ETH-Fluka) reproduced with $\delta^{202} \mathrm{Hg}=-1.44 \% 0 \pm 0.12 \%, \Delta^{199} \mathrm{Hg}=0.07 \pm 0.05 \%$ o, $\Delta^{200} \mathrm{Hg}=0.01 \pm 0.06 \%$ 270 and $\Delta^{201} \mathrm{Hg}=0.03 \pm 0.06 \%(2 \sigma, \mathrm{n}=21)$ and the process standard (Montana Soil, NIST-2711), combusted in the oven-enrichment system after every 10 samples reproduced at $\delta^{202} \mathrm{Hg}=-0.12 \pm 0.10 \%, \Delta^{199} \mathrm{Hg}=-0.23 \pm 0.07 \%$, ${ }_{273} \Delta^{200} \mathrm{Hg}=0.00 \pm 0.04 \%$ and $\Delta^{201} \mathrm{Hg}=-0.18 \pm 0.02 \%$ \% $(2 \sigma, \mathrm{n}=10)$, consistent with previously published values $[54,57,58,59,60,61]$. The accurate measurement of $\mathrm{Hg}$ isotope signatures in organic soil matrices was validated 276 by measurements of peat samples low in ambient $\mathrm{Hg}$ spiked with inorganic $\mathrm{Hg}(\mathrm{II})$, consistent with direct measurements of the inorganic $\mathrm{Hg}$ (II)-salt (ESI 
Table S9) [33].

279 Total dissolved $\mathrm{Hg}$ concentrations were measured using cold vapor atomic fluorescence spectrometry (CV-AFS; Millennium Merlin, PS Analytical) and DOC $(<0.45 \mu \mathrm{m})$ was measured using a total organic carbon analyzer (TOC, Dimatoc 2000, Dimatec). For solid samples, carbon and nitrogen were measured by a CHNS analyzer (LECO) and the total Hg concentration was measured by combustion atomic absorption spectrometry (LECO AMA-254).

285 Element concentrations $(\mathrm{Z}>11)$ were measured by energy-dispersive X-ray fluorescence analysis (XRF; Spectro-X-Lab 2000, Spectro) of pressed pellets of powdered samples with wax (4 g sample, $0.9 \mathrm{~g}$ wax).

Radiocarbon signatures were measured on the soil sample powders and freeze-dried organic carbon of the water samples after pre-enrichment. Samples were graphitized and high precision ${ }^{14} \mathrm{C}$ signatures measured on an accelerator mass spectrometer (AMS, ETH Zurich) [62]. Since the majority of samples contained post-bomb carbon, the radiocarbon data are reported as fraction relative to modern carbon $\left(\mathrm{F}^{14} \mathrm{C}\right)$ according to Reimer et al.[63].

\subsection{Mixing model}

The contribution of litter-derived and precipitation-derived $\mathrm{Hg}$ was calculated using a binary mixing model taking into account triple $\mathrm{Hg}$ isotope signatures $\left(\delta^{202} \mathrm{Hg}, \Delta^{199} \mathrm{Hg}, \Delta^{200} \mathrm{Hg}\right)$ of the litter endmember from the local site and previously published data for $\mathrm{Hg}$ in precipitation [33]. The $\mathrm{Hg}$ contribution of different soil horizons to the catchment runoff was calculated with a mixing model using $\mathrm{Hg}$ isotope signatures as tracers. We assumed that the $\mathrm{Hg}$ isotope signature in the dissolved phase was a mixture of the different sources, represented by the bulk soil horizon measurements and that there was no $\mathrm{Hg}$ isotope fractionation associated with leaching of $\mathrm{Hg}$ from the soils. Thus, the signatures of the source pools $(\mathrm{Oe} / \mathrm{He}, \mathrm{Oa} / \mathrm{Ha}$, and $\mathrm{E}+\mathrm{B}$ horizon) were treated as conservative tracers. The limitations of the conservative tracer approach will be addressed in the discussion. The distribution of the source signals was modeled based on the measured results (average and standard deviation, ESI Table ESI) using the pseudo-random number 

of the soil samples were simulated with a Monte Carlo simulation approach (details in ESI).

\section{$3 \quad$ Results}

\subsection{Validation of pre-enrichment using ultrafiltration}

The validation test of the pre-enrichment method using ultrafiltration showed $\mathrm{Hg}(93 \%$ - 97\%) (Table 1). About $10 \%$ of the total organic carbon and $\mathrm{Hg}$ was associated with the rinse fraction, likely representing the dead volume in the ultrafiltration system and sorption to the membrane. Based on the good mass balance for DOC and $\mathrm{Hg}$ the blank levels are expected to be below $5 \%$ of the total $\mathrm{Hg}$ of a sample and thus did not have a significant effect 321 on the measured $\mathrm{Hg}$ isotope signatures. The retentate of the SM sample

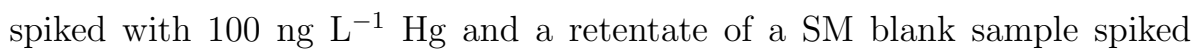

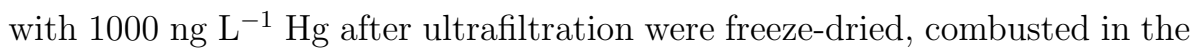
324 two-stage oven system and analyzed for $\mathrm{Hg}$ isotope signatures. The yield of $\mathrm{Hg}$ in the trap solution of the oven combustion system compared to the amount of $\mathrm{Hg}$ in the retentate was $83 \%$ for the 100 ppt spiked SM sample and on average $88 \%( \pm 14 \%)$ for the boreal runoff samples (ESI Table S7). The Hg isotope signature of the ETH-Fluka standard spiked to the SM water and processed by the ultrafiltration, freeze-drying and two-stage oven combustion method was identical within analytical uncertainty (2SD) to the results of the directly measured ETH-Fluka standard (Table 1), confirming that the enrichment procedure did not cause any $\mathrm{Hg}$ isotope fractionation. We therefore conclude that the sample enrichment using ultrafiltration is a suitable method to measure $\mathrm{Hg}$ isotope signatures of aqueous samples with high NOM concentrations. 


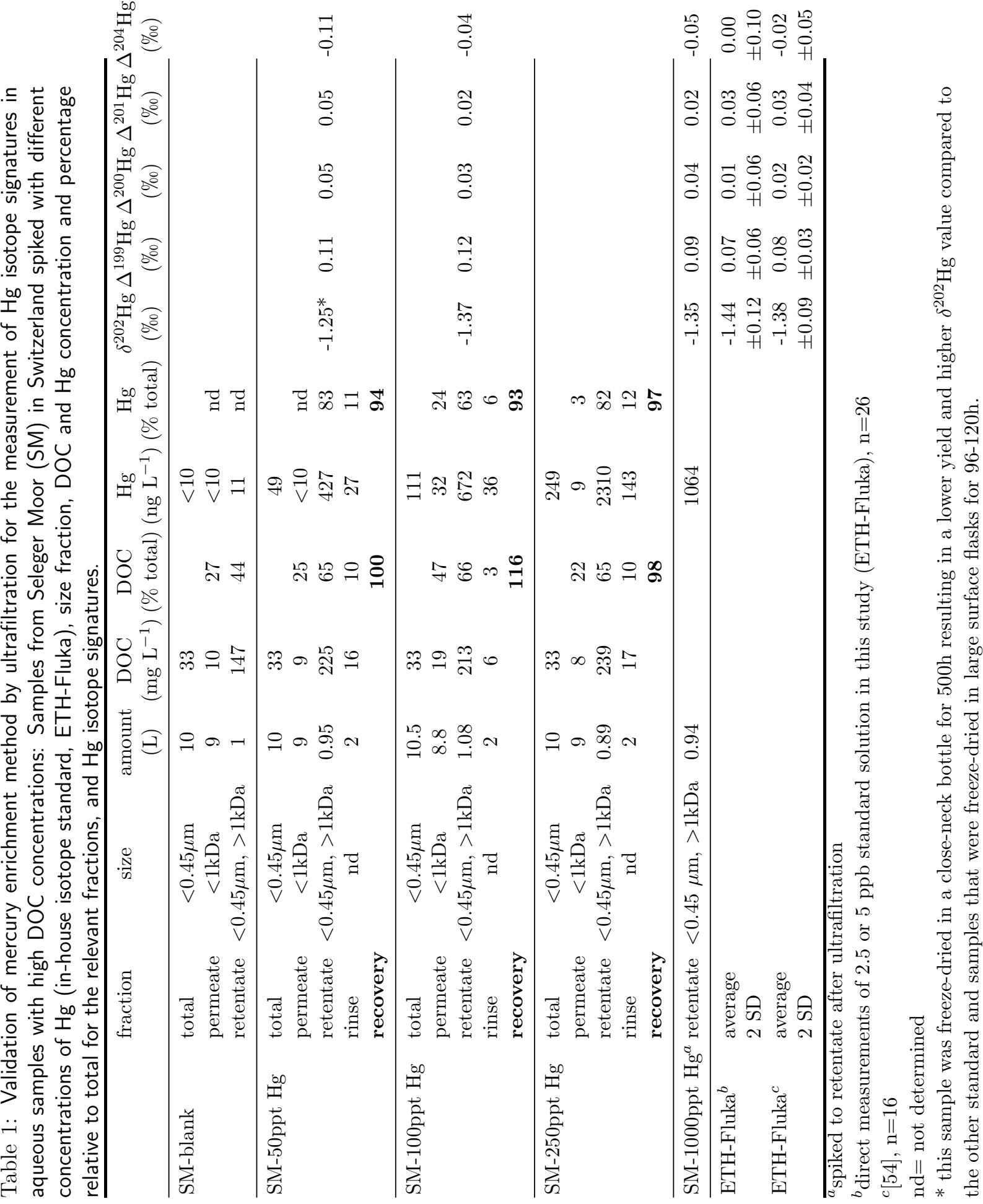




\section{2 $\mathrm{Hg}$ isotope signatures in clear-cut soils and catch- ment runoff}

339 For all four forest sites, $\mathrm{Hg}$ associated with NOM in catchment runoff had negative $\delta^{202} \mathrm{Hg}(-2.29 \%$ to $-1.99 \%), \Delta^{199} \mathrm{Hg}(-0.42 \%$ to $-0.33 \%$ ) and $\Delta^{200} \mathrm{Hg}$ values (-0.12\% to $-0.01 \%$ ) (Figure 2 a,d,f and i). Hg isotope signatures in soil samples of clear-cut sites were characterized by isotopically light $\delta^{202} \mathrm{Hg}$ signature (MDF, $\delta^{202} \mathrm{Hg}=-2.48 \%$ to $-1.64 \%$ ), a depletion in odd-mass isotopes (odd-MIF, $\Delta^{199} \mathrm{Hg}=-0.49 \%$ to $-0.31 \%$ ) and small negative even-MIF ( $\Delta^{200} \mathrm{Hg}=-0.08 \%$ to $0 \%$ ) (Table 2, Figure $2 \mathrm{~d}$ and $\mathrm{i}$ ). The $\delta^{202} \mathrm{Hg}, \Delta^{199} \mathrm{Hg}$ and $\Delta^{200} \mathrm{Hg}$ signatures of the clear-cut soil and runoff samples were in the range of the $\mathrm{Hg}$ isotope signatures measured in the soils of the same boreal forest catchments [33] $\left(\delta^{202} \mathrm{Hg}=-2.56 \%\right.$ to $-1.55 \%$ and $\Delta{ }^{199} \mathrm{Hg}=-0.48 \%$ to $-0.24 \%$ )[33] (Figure $2 \mathrm{a}$,d,f and i) and consistent with other observations in soils, generally reporting negative $\delta^{202} \mathrm{Hg}$ and $\Delta^{199} \mathrm{Hg}$ values $[29,31,32,34,64,65]$. The water sample of the larger Lillsele stream had MDF $\left(\delta^{202} \mathrm{Hg}=-2.01 \%\right)$ and $\operatorname{MIF}\left(\Delta^{199} \mathrm{Hg}=-0.33 \% 0\right)$ signatures similar to the four runoff samples from the boreal catchments which are draining into the Lillsele stream (Table 3). Also the lake inlet (VK-Inlet) had MDF $\left(\delta^{202} \mathrm{Hg}=-1.76 \%\right)$ and MIF $\left(\Delta^{199} \mathrm{Hg}=-0.25 \%\right)$ signatures similar to the runoff samples from the boreal catchments (Table 2). The $\delta^{202} \mathrm{Hg}$ signature

357 of the lake outlet, representing the mixed lake water (VK-outlet), was similar to the lake inlet $\left(\delta^{202} \mathrm{Hg}=-1.92 \%\right.$ ) , however its $\Delta^{199} \mathrm{Hg}$ signature was different from all soil and runoff samples $\left(\Delta^{199} \mathrm{Hg}=0.04 \%\right)$. All soil and 360 natural water samples had a $\Delta^{199} \mathrm{Hg} / \Delta^{201} \mathrm{Hg}$ ratio of $\approx 1$ within analytical uncertainty and the samples did not exhibit an anomaly in $\Delta^{200} \mathrm{Hg}$ (Table 3). The radiocarbon signature $\left(\mathrm{F}^{14} \mathrm{C}\right)$ in the runoff $(1.10$ and 1.11 for reference site 1 and 2, respectively, Figure $2 \mathrm{~b}$ and $\mathrm{g}$ ) indicated that the presence of post-bomb carbon was similar to the radiocarbon signatures measured for the organic topsoil horizons $\mathrm{Oe} / \mathrm{He}(1.12 \pm 0.01$ for both sites) and different from the underlying organic $\mathrm{Oa} / \mathrm{Ha}(0.95 \pm 0.06$ and $1.20 \pm 0.05)$ and mineral $\mathrm{E}+\mathrm{B}$ $(1.01 \pm 0.04$ and $1.05 \pm 0.05)$ horizons (ESI Table S4). We did not observe any statistical difference in $\mathrm{F}^{14} \mathrm{C}$ between the bulk soil and the extracted humic 
1

2

3

4

5

6

7

8
${ }_{369}$ acid fraction of selected soil samples (Figure S5), supporting that the $\mathrm{F}^{14} \mathrm{C}$ leaching from a soil horizon is similar to its bulk $\mathrm{F}^{14} \mathrm{C}$ signature. The $\mathrm{Hg} / \mathrm{C}$ ratios in the catchment runoff was generally lower (average of all 4 sites: 0.31

${ }_{372} \mu \mathrm{g} \mathrm{g}^{-1}$ ) than in the soils. The $\mathrm{Hg} / \mathrm{C}$ ratio in soil increased with soil depth from the uppermost horizons (Oe/He, average: $0.42 \mu \mathrm{g} \mathrm{g}^{-1}$ ) to the underlying organic $\mathrm{Oa} / \mathrm{Ha}$ (average: $0.68 \mu \mathrm{g} \mathrm{g}^{-1}$ ) and mineral $\mathrm{E}+\mathrm{B}$ (average: 1.21 ${ }_{375} \mu \mathrm{g} \mathrm{g}^{-1}$ ) horizons (Figure $2 \mathrm{c}, \mathrm{e}, \mathrm{h}$, and $\mathrm{j}$, Table S2). 
Table 2: $\mathrm{Hg}$ isotope data of soil samples from clear-cut sites. Samples were taken from 5 soil profiles with increasing distance to the stream (P1 to P5). The soil samples are categorized as $\mathrm{Oe} / \mathrm{He}$ for the organic surface horizons, $\mathrm{Oa} / \mathrm{Ha}$ for underlying more decomposed organic horizons, and $\mathrm{B}$ for the mineral horizon.

\begin{tabular}{lcccccc}
\hline Sample & $\delta^{202} \mathrm{Hg}$ & $\Delta^{199} \mathrm{Hg}$ & $\Delta^{200} \mathrm{Hg}$ & $\Delta^{201} \mathrm{Hg}$ \\
& $(\%)$ & $(\% 0)$ & $(\% 0)$ & $\begin{array}{c}\left.\Delta^{204} \mathrm{Hg}\right) \\
(\% 0)\end{array}$ & $\Delta^{199} \mathrm{Hg} / \Delta^{201} \mathrm{Hg}$ \\
\hline clear-cut & site - 1 & & & & & \\
P2-He & -1.64 & -0.43 & -0.03 & -0.40 & 0.02 & 1.08 \\
P3-Oe & -2.21 & -0.33 & -0.01 & -0.32 & 0.07 & 1.03 \\
P4-Oe & -2.27 & -0.43 & -0.03 & -0.43 & 0.11 & 0.98 \\
P5-Oe & -2.04 & -0.31 & 0.00 & -0.28 & 0.03 & 1.08 \\
P2-Ha & -1.68 & -0.43 & -0.08 & -0.43 & -0.03 & 1.00 \\
P3-Oa & -1.76 & -0.33 & -0.06 & -0.28 & 0.10 & 1.16 \\
P4-Oa & -2.00 & -0.34 & -0.01 & -0.34 & 0.10 & 0.99 \\
P5-B & -1.76 & -0.41 & -0.03 & -0.40 & 0.05 & 1.04 \\
\hline clear-cut & site - 2 & & & & & \\
P2-He & -2.48 & -0.49 & -0.02 & -0.46 & 0.07 & 1.08 \\
P3-He & -2.20 & -0.39 & -0.07 & -0.38 & -0.04 & 1.02 \\
P4-He & -2.13 & -0.38 & -0.05 & -0.34 & 0.02 & 1.12 \\
P5-Oe & -2.21 & -0.37 & -0.04 & -0.29 & -0.01 & 1.29 \\
P2-Ha & -1.91 & -0.47 & -0.07 & -0.39 & -0.01 & 1.19 \\
P3-Ha & -1.75 & -0.44 & -0.03 & -0.38 & 0.04 & 1.17 \\
P4-Ha & -1.76 & -0.44 & -0.02 & -0.44 & -0.02 & 1.01 \\
P5-Oa & -1.93 & -0.31 & -0.06 & -0.33 & 0.03 & 0.95 \\
\hline
\end{tabular}




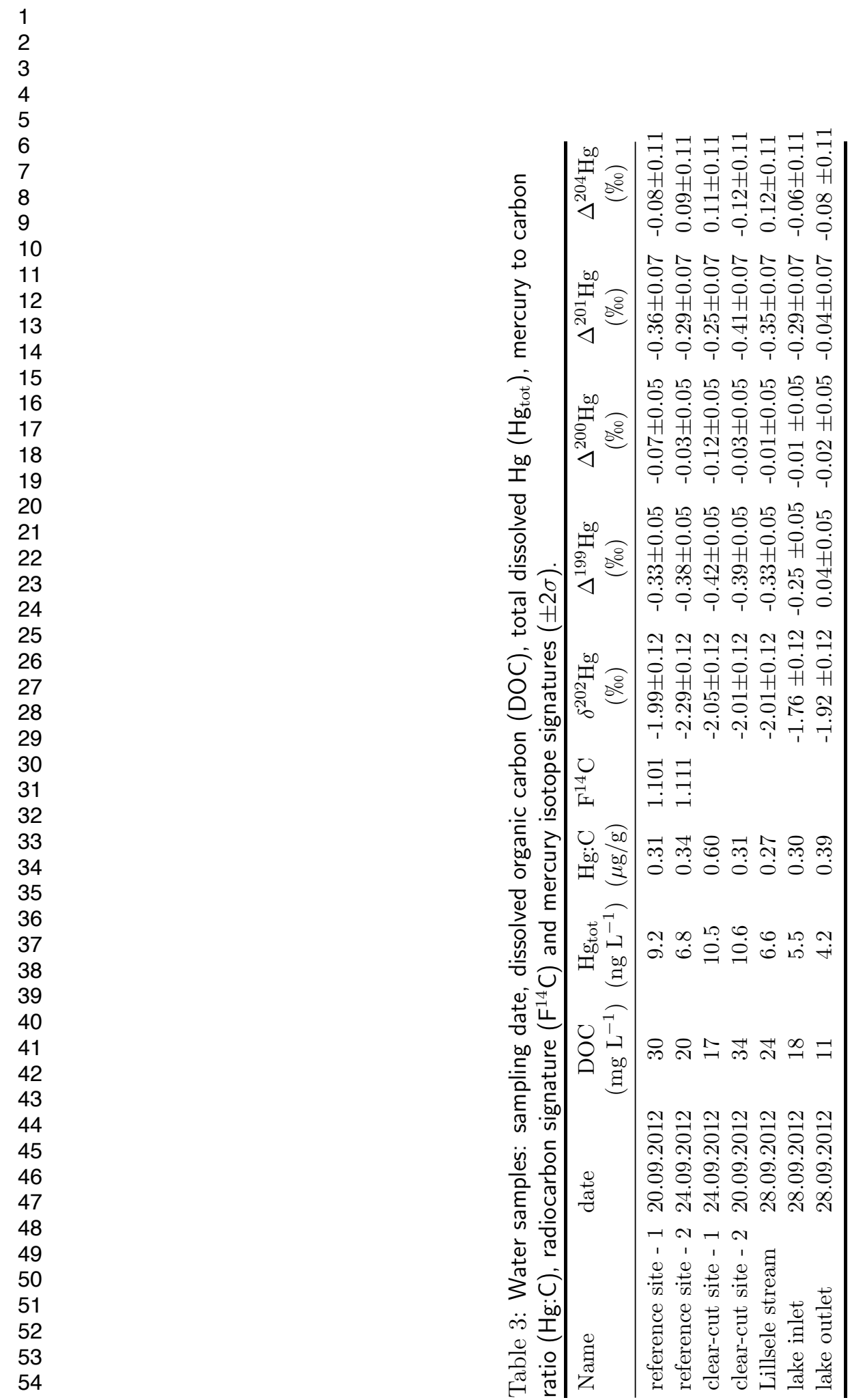

55

56

57 
a)

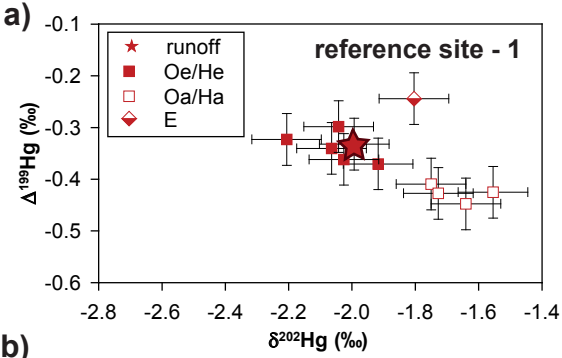

b)

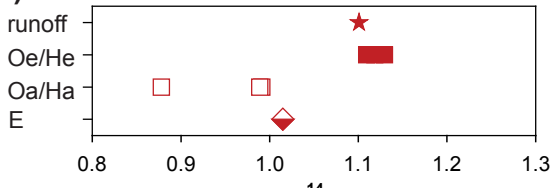

c)

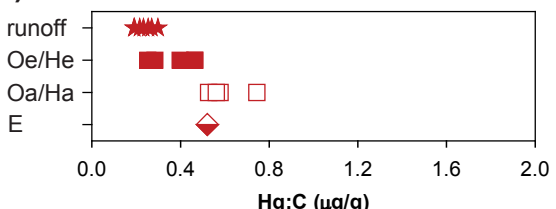

d)

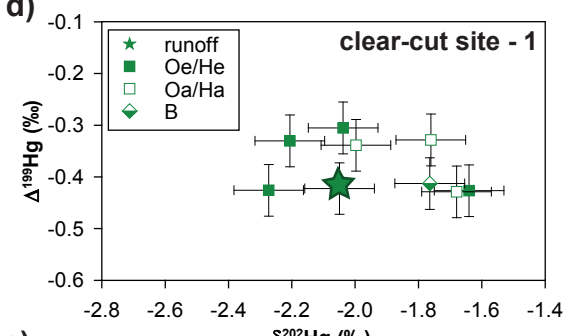

\section{e)}

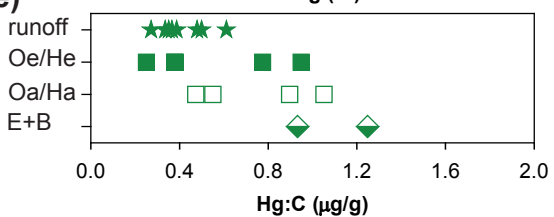

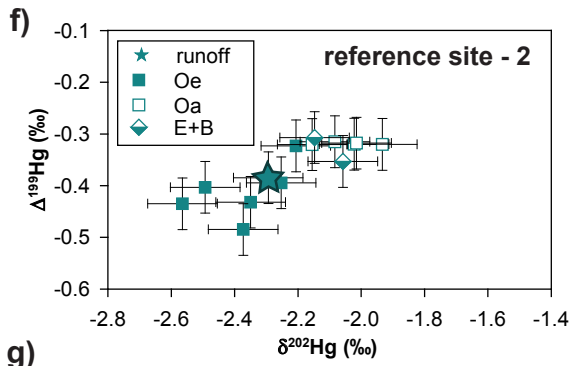

g)

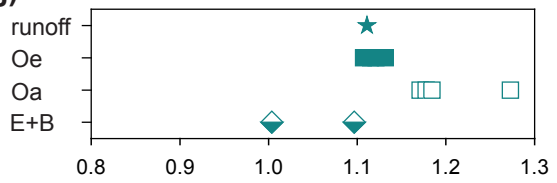

h)

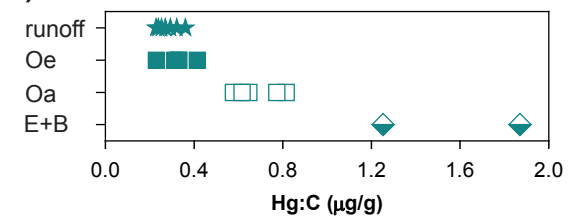

i)

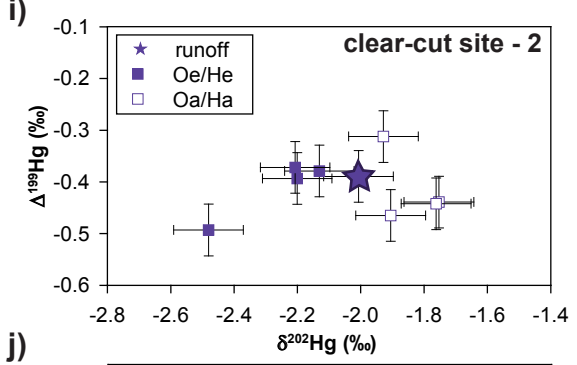

j)

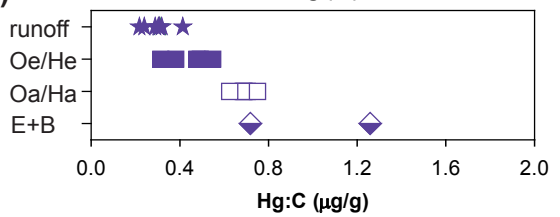

Figure 2: Water sample results (stars) of catchment runoff in comparison with major pools of boreal forest soils in four sites (two intact forests (reference site 1 and 2) and two harvested forest sites (clear-cut site 1 and 2): Hg isotope signatures ( $\delta^{202} \mathrm{Hg}$ vs. $\Delta^{199} \mathrm{Hg}$, panels a, d, f and i), radiocarbon signatures $\left(\mathrm{F}^{14} \mathrm{C}\right.$, panels b and $\left.\mathrm{g}\right)$ and $\mathrm{Hg}$ to carbon ratios ( $\mathrm{Hg}$ :C, panels $\mathrm{c}, \mathrm{e}, \mathrm{h}$ and $\mathrm{j}$ ). Soil data from clear-cut sites are from this study, soil data of reference sites are from Jiskra et al.[33]. 


\subsection{Hg isotope signatures of boreal catchment runoff}

The runoff samples were collected on days with no precipitation (Figure S4) and the runoff represented moderate to high flow conditions, typical for fall [21]. Precipitation, a potentially important source for $\mathrm{Hg}$ in soil runoff, was previously observed to have a $\mathrm{Hg}$ isotope signature $\left(\delta^{202} \mathrm{Hg}=-1.7 \%\right.$ o to 0.5 $\% 0$ and $\Delta^{199} \mathrm{Hg}=-0.1 \%$ to $1.1 \% 0$, 5- to 95 -percentile, $<25 \mathrm{ng} \mathrm{L} \mathrm{L}^{-1}, \mathrm{n}=58$ ) $[25,26,27,28,29,31]$ which is distinct from the soil and runoff samples. Using the binary mixing model between litter- and precipitation-derived $\mathrm{Hg}$ 387 based on triple $\mathrm{Hg}$ isotope signatures $\left(\delta^{202} \mathrm{Hg}, \Delta^{199} \mathrm{Hg}, \Delta^{200} \mathrm{Hg}\right.$ ) established in Jiskra et al. [33], we calculated the contribution of precipitation-derived $\mathrm{Hg}$ in the runoff samples. The calculated contribution of precipitation-derived $\mathrm{Hg}$ in runoff samples was on average $13 \%( \pm 5 \%)$ for all sites and thus not significantly different from the average contribution of precipitation-derived $\mathrm{Hg}$ reported for the soil samples (average $10 \%$ ) [33]. Systematically positive anomalies on the even-mass isotopes (average $\Delta^{200} \mathrm{Hg}=0.27 \%$ ) were reported for precipitation $[25,26,27,28,29,31]$, whereas atmospheric $\mathrm{Hg}^{0}$ is associated with slight negative $\Delta^{200} \mathrm{Hg}$ values (average -0.05 \% ) [25, 30, 31, 32, 66].

396 Foliar uptake of atmospheric $\mathrm{Hg}^{0}$ is associated with a large MDF fractionation towards negative $\delta^{202} \mathrm{Hg}$ values, whereas there is no fractionation in $\Delta^{199} \mathrm{Hg}$ and $\Delta^{200} \mathrm{Hg}[29,31,67]$. As potential post-deposition processes (e.g. 399 re-emission) appear not to affect $\Delta^{200} \mathrm{Hg}$ isotope signatures, it has been suggested that $\Delta^{200} \mathrm{Hg}$ isotope signatures are a robust fingerprint to trace atmospheric sources in terrestrial [31] and aquatic [68] ecosystems. The significant 402 negative $\Delta^{200} \mathrm{Hg}$ anomalies in soil $(\mathrm{p}<0.01$, z-test $)$ and runoff $(\mathrm{p}<0.01$, z-test $)$ samples (Figure 3) provides strong support that atmospheric $\mathrm{Hg}^{0}$, and not precipitation-derived $\mathrm{Hg}^{\mathrm{II}}$ represents the dominant source of atmospheric $\mathrm{Hg}$ deposition for the boreal forest catchment studied here. This finding is in agreement with the calculated low contribution of precipitation-derived $\mathrm{Hg}$ in the runoff samples. We therefore conclude that at days without rainfall and 
September 2012, NOM-bound Hg in runoff was dominated by Hg mobilized from the soil horizons and additional direct runoff of precipitation-derived

${ }_{411} \mathrm{Hg}$ played no significant role. This is in agreement with hydrological studies showing that runoff during rain events in fall is dominated by "old soil water" in these types of boreal forest catchments dominated by Podzols/Histosols

414 along riparian zones of streams [69]. The sample of the nearby lake studied here and other lake samples from Ontario, Canada [43] (Figure 3) were characterized by stable $\mathrm{Hg}$ isotope signatures that suggest higher contributions

${ }_{417}$ ( $16 \pm 10 \%$ for the nearby lake and $42 \pm 26 \%$ for Ontario) of precipitationderived Hg.

The $\mathrm{Hg}$ in the catchment runoff could potentially be affected by $\mathrm{Hg}$ iso${ }_{420}$ tope fractionation caused by secondary processes resulting in an offset of the runoff isotope signature compared to the soils. In case the mobilization of $\mathrm{Hg}$ from the soil would be controlled by an exchange of $\mathrm{Hg}$ between NOM in ${ }_{423}$ soils and NOM in runoff, involving inorganic $\mathrm{Hg}$ (II) complexes in solution, an enrichment of heavy isotopes in the dissolved phase would be expected as observed for $\mathrm{Hg}$ (II) sorption to thiol-groups [53]. However, the process 426 of $\mathrm{Hg}$ desorption from natural organic matter (NOM) has been shown to be very slow [70], and therefore it appears more plausible that $\mathrm{Hg}$ is mobilized from soils along with $\mathrm{NOM}$, while the strong $\mathrm{Hg}$ (II)-NOM complexes remain intact. Reductive loss of $\mathrm{Hg}$ during transport from the soil to the runoff could represent another plausible cause for Hg isotope fractionation; however the samples were taken in very small creeks and the exposure time to ${ }_{432}$ sunlight was minimal. Furthermore, all known reduction mechanisms cause an enrichment of lighter isotopes in the reduced $\mathrm{Hg}^{0}$ phase $[71,72,73]$. Both of these potential secondary processes would lead to heavier $\delta^{202} \mathrm{Hg}$ isotope 435 signatures in the runoff, however we see no evidence for secondary processes in the runoff samples which were characterized by relatively light $\delta^{202} \mathrm{Hg}$ values $\left(\delta^{202} \mathrm{Hg}=-1.99 \%\right.$ to $-2.29 \%$ ). A third potential secondary process 438 would be the change in speciation during transfer in the runoff or sample processing from $\mathrm{HgS}$ nanoparticles to thermodynamically more stable $\mathrm{Hg}$ $\mathrm{SH}$ complexes with NOM. The Hg isotope fractionation between dissolved ${ }_{441} \mathrm{Hg}(\mathrm{II})$ and thiol-bound $\mathrm{Hg}$ [53] and $\mathrm{Hg}$-sulfide [61] is very similar (-0.6 \%o 
in $\delta^{202} \mathrm{Hg}$ with respect to aqueous $\left.\mathrm{Hg}(\mathrm{II})\right)$. We therefore expect that the potential change in speciation between $\mathrm{Hg}$-SH and $\mathrm{Hg}$-S does not lead to a isotope signatures of the runoff samples were in the range of the soil samples we suggest that effects from $\mathrm{Hg}$ isotope fractionation caused by secondary tracer to elucidate source and flow pathways of $\mathrm{Hg}$. We therefore used a mixing model to describe the contributions of different soil horizons, exhibiting distinct end-member signatures, to the $\mathrm{Hg}$ in the runoff. All runoff data were well described by a mixing of $\mathrm{Hg}$ isotope signatures from different soil horizons. The results of the mixing model suggest that for most of the sites the majority of the $\mathrm{Hg}$ originated from the surface Oe/He horizons with $71 \pm 17 \%$ and $58 \pm 18 \%$ for the reference sites 1 and 2 , and $55 \pm 25 \%$ and $48 \pm 22 \%$ for the clear-cut sites 1 and 2, respectively. The remaining fraction (28\%-52

${ }_{456} \%$ ) originated from the deeper more humified organic $\mathrm{Ha} / \mathrm{Oa}$ horizon and the mineral E+B horizon (Figure 4a, ESI Table S6).

\subsection{Comparison of $\mathrm{Hg}$ isotope signatures to radiocar- bon signatures and $\mathrm{Hg}: \mathrm{C}$ ratios}

The radiocarbon signatures $\left(\mathrm{F}^{14} \mathrm{C}\right)$ of $\mathrm{NOM}$ in the runoff of two reference sites were identical to the radiocarbon signatures reported for the Oe/He

462 horizons [33] (Figure $2 \mathrm{~b}$ and $2 \mathrm{~g}$ ). A high fraction of NOM in runoff originating from uppermost $\mathrm{Oe} / \mathrm{He}$ horizons would be in agreement with a lysimeter study, reporting that Oe horizons of Podzols are the dominant source for NOM in soil leachates [74]. Another study on boreal spruce forests in Sweden, however, indicated that NOM in soil solution collected from mineral B horizons was derived from the mineral horizon itself [75]. Despite the fact ${ }_{468}$ that there are large stocks of old carbon (100 to 1000 years, $\left.\mathrm{F}^{14} \mathrm{C}<1\right)$ mainly in Ha horizons of Histosols [33], the runoff was characterized by the presence of post-bomb carbon $\left(\mathrm{F}^{14} \mathrm{C}>1\right.$, Figure 2$)$, and thus dominated by young 471 NOM from the Oe/He horizons, in agreement with previous findings based on radiocarbon signatures $[76,77,78]$. NOM has a governing role for the 
mobility of $\mathrm{Hg}$ in soils, based on the high binding affinity of thiol groups in

${ }_{474}$ organic matter for $\mathrm{Hg}(\mathrm{II})[6]$. We observed an increase of the $\mathrm{Hg}$ :C ratios with soil depth both in the clear-cut samples presented here and the reference samples presented in Jiskra et al.[33], similar to previous observations

$477[7,79,80,81,82]$. The Hg:C ratios of the runoff samples were similar to the $\mathrm{Hg}$ : $\mathrm{C}$ ratios of the Oe/He horizons of the corresponding catchment (Figure $2 \mathrm{c}, 2 \mathrm{e}, 2 \mathrm{~h}$ and $2 \mathrm{j}$ ) and generally lower than $\mathrm{Hg}: \mathrm{C}$ ratios in the $\mathrm{Oa} / \mathrm{Ha}$ and 480 mineral horizons.

Many studies observed a correlation between dissolved Hg and NOM concentration $[7,8,9,10,11,83]$. Based on this correlation, it has been suggested that it may be possible to trace the origin of $\mathrm{Hg}$ to soil horizons by comparing the $\mathrm{Hg}: \mathrm{C}$ ratios in the runoff with $\mathrm{Hg}: \mathrm{C}$ ratios of the solid phases [7]. However, other studies have observed independent dynamics of $\mathrm{Hg}$ and NOM, e.g., after snowmelt [84]. We observed slightly lower Hg:C ratios in the runoff compared to the uppermost Oe/He horizons. This difference might originate from a larger mobility of young NOM derived from the decomposition of fresh litter which exhibits the lowest $\mathrm{Hg}$ :C ratios. With our sampling strategy, where we sampled discrete soil horizons of 5 to $15 \mathrm{~cm}$ thickness, we are not able to resolve younger and potentially more mobile soil pools. The

492 lower $\mathrm{Hg}: \mathrm{C}$ ratios observed in the runoff speak against a preferential leaching of $\mathrm{HgS}$ nanoparticles from soils to runoff, where one would expect higher $\mathrm{Hg}: \mathrm{C}$ ratios in the terrestrial runoff.

495 In our study, the fingerprint of $\mathrm{Hg}$ isotope ratios, a potential tracer for the $\mathrm{Hg}$ source, the radiocarbon signature, a tracer for the NOM source, and the $\mathrm{Hg}$ :C ratio in the runoff samples were all in good agreement with the respective fingerprints of the Oe/He horizons (Figure 3a). The similarity of the three signatures affirms the strong link between NOM and $\mathrm{Hg}$.

\subsection{Mobility of $\mathrm{Hg}$ in boreal forest soils}

We calculated the mobility of $\mathrm{Hg}$ from the different soil horizons as percentage of monthly outflow relative to the total soil horizon pool (Figure 4b) based on estimates for the Hg pool sizes in the soils by Kronberg et al. [22] (ESI Table 

We have previously reported that forest harvest of the clear-cut sites 1 and 2 have led to an increase in $\mathrm{MeHg}$ concentration in the soil pool from $<1$ ${ }_{531} \%$ to $\approx 7 \%[21,22]$. Comparing the bulk $\mathrm{Hg}$ isotope composition in the soil horizons (Oe/He and Oa/Ha, Table 2) of the clear-cut sites with the respective soil horizons of the reference sites 1 and 2 [33], we find no sig534 nificant difference between the two sites ( $\mathrm{p}>0.4$, t-test). We conclude that 
the processes associated with forest harvest did not affect the large bulk soil $\mathrm{Hg}$ pool in the two years between clear-cut and soil sampling to an extent that would alter the $\mathrm{Hg}$ stable isotope signatures. The harvesting of forest by clear-cutting has been shown to have significant effects on $\mathrm{MeHg}$ concentrations in the catchment runoff and in biota of the associated aquatic ecosystems $[9,16,17,18,19,20,21,22]$. Forest clear-cut and site preparation has been shown to enhance the NOM mobilization and runoff flux compared to intact reference sites [89, 90, 21]. The $\mathrm{Hg}$ isotope signatures in

${ }_{543}$ the runoff of clear-cut sites could potentially indicate a higher contribution of $\mathrm{Hg}$ from underlying $\mathrm{Oa} / \mathrm{Ha}$ horizons $(\approx 50 \%)$ as compared to the reference sites (Figure 3), however this difference was not significant. Similarly, radiocarbon signatures revealed a mobilization of old carbon from peat soils impacted by land-use change [78, 91]. Higher sample sizes would be needed to get a conclusive result on the effect of forest harvest on the mobilization 549 of $\mathrm{Hg}$ from lower soil horizons.

\subsection{Conclusion}

Using a pre-enrichment method based on ultrafiltration, we measured $\mathrm{Hg}$ 552 isotope signatures of $\mathrm{Hg}$ associated with high molecular weight NOM from boreal forest runoff. Whereas the analytical pre-enrichment technique presented here has proven useful to analyze $\mathrm{Hg}$ isotope composition in NOM-rich 555 water, it relied on large sample quantities and was very labour intensive. The application of the ultrafiltration technique will allow to further investigate specific questions on the shuttling of $\mathrm{Hg}$ by NOM, and analyzing $\mathrm{Hg}$ isotopes in natural surface water with high NOM concentration. In order to process larger quantities of samples and analyze $\mathrm{Hg}$ isotopes in surface waters exhibiting lower NOM concentrations alternative approaches, e.g. based on purge and trap methods might prove more suitable. We found that the $\mathrm{Hg}$ isotope signatures in the boreal soil runoff were very similar to the $\mathrm{Hg}$ isotope signatures of the surrounding soils and conclude that the majority of $\mathrm{Hg}$ in the runoff originates from the deposition of atmospheric $\mathrm{Hg}^{0}$ through vegetation uptake. We suggest that the different $\mathrm{Hg}$ isotope signatures found 
in different soil horizons can be useful to assess the contribution of different 567 soil horizons to terrestrial runoff. This approach might serve very useful to assess the future development of $\mathrm{Hg}$ loads in runoff with changing atmospheric Hg concentrations and climatic conditions. The exploratory data on $\mathrm{Hg}$ isotope signatures in runoff from boreal forest soils presented here do not allow extrapolation to global scale, as they are limited on a temporal and spatial resolution. The findings however illustrate the potential of $\mathrm{Hg}$ stable ${ }_{573}$ isotopes to trace the source of $\mathrm{Hg}$ from atmospheric deposition through a terrestrial ecosystem. Rivers fluxes, transporting terrestrial and anthropogenic $\mathrm{Hg}$, represents an important $\mathrm{Hg}$ source to the oceans [92, 93]. Foliar uptake of atmospheric $\mathrm{Hg}^{0}$ was found to be the dominant atmospheric deposition pathway to many terrestrial ecosystems around the globe [29, 31, 32, 33, 34, 94]. As a result, soils are generally characterized by negative $\delta^{202} \mathrm{Hg}$ values from 579 the isotopic fractionation during foliar uptake and $\Delta^{199} \mathrm{Hg}$ and $\Delta^{200} \mathrm{Hg}$ values similar to atmospheric $\mathrm{Hg}^{0}[29,31,32,33,34,94]$. This characteristic "terrestrial" isotopic fingerprint has the potential to trace the contribution 582 of terrestrial $\mathrm{Hg}$ e.g. to living biota [40, 42, 95] or sediments in lakes [68] and the ocean $[96,97]$.

\section{Acknowledgments}

${ }_{585}$ We would like to thank Kurt Barmettler for support in the soil chemistry laboratory and Colin Maden and Robin Smith for assistance in the isotope geochemistry laboratory. We are grateful to Urs Menet, Donat Niederer,

${ }_{588}$ Daniel Schnarwiler and Andreas Suesli for their help in the manufacturing of the two-stage combustion oven. We thank Irka Hajdas for measuring the radiocarbon signatures and Markus Meili for measuring $\mathrm{Hg}$ concentrations in water samples. We thank Alexander Brunner, Christa Bodmer, and Alexandra Metzger for help with sample preparation and analyses and Jeroen E. Sonke for comments on an earlier version of the manuscript. This research was funded by ETH Zurich (research grant ETH-15 09-2) and the Swedish Research Council for Environment and Spatial Planning (FORMAS, no. 292009-1207). We thank the associate editor and three anonymous reviewers 
597 for their helpful comments. 

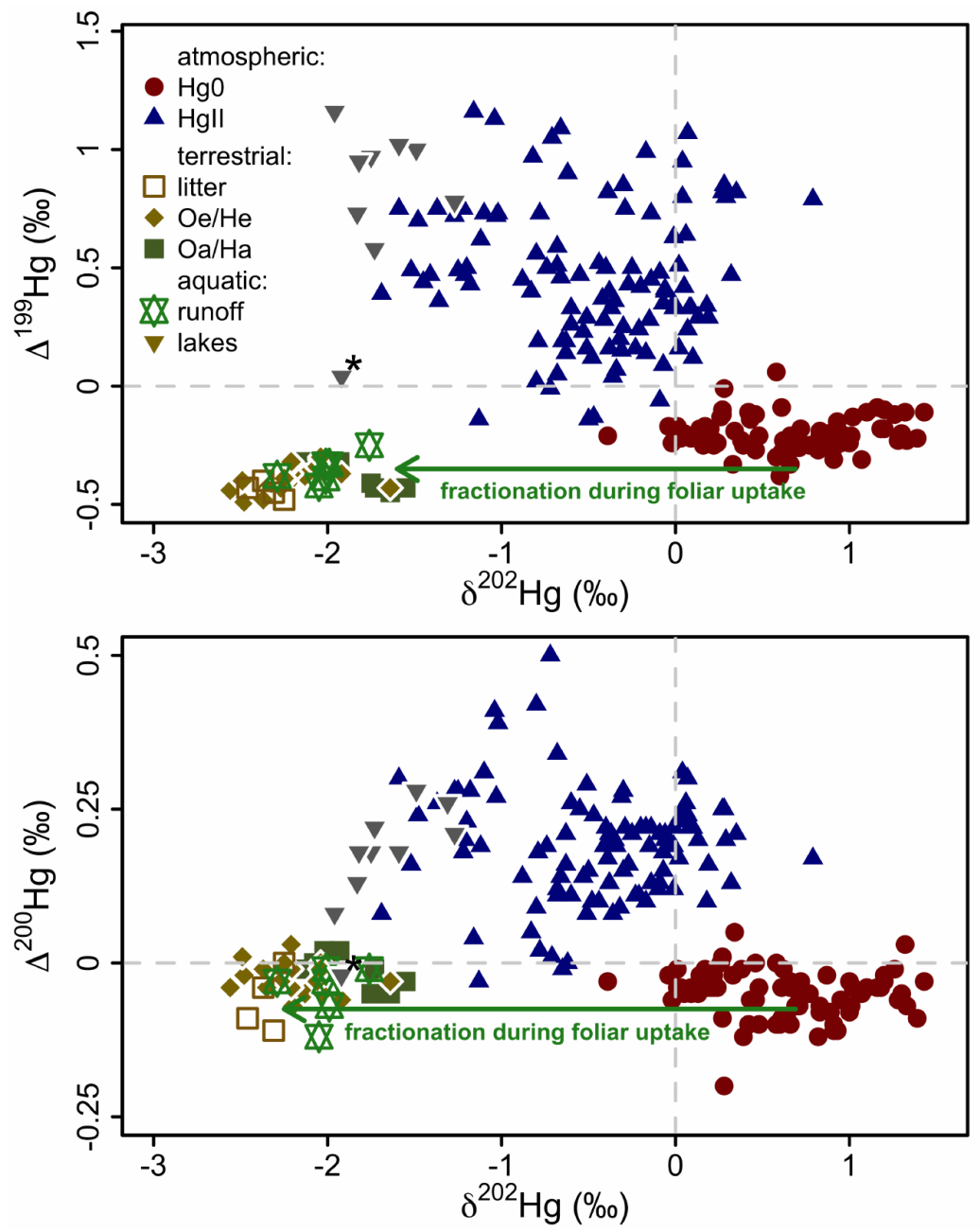

Figure 3: Comparison of terrestrial $\mathrm{Hg}$ isotope signatures (litter, soil) and runoff of the boreal forest catchment studied here and in Jiskra et al. [33] with previously published values for atmospheric gaseous elemental $\mathrm{Hg}^{0}$ and oxidized $\mathrm{Hg}$ in precipitation $\mathrm{Hg}^{\mathrm{II}}[25,26,27,28,29,30,28,31,32]$. The lake sample marked with * is from the lake close to the boreal forest catchment, all other lake samples are from Ontario, Canada published by Chen et al.[43]. The $\mathrm{Hg}$ isotope fractionation trajectory associated with foliar uptake of $\mathrm{Hg}^{0}$ is marked by the arrow $[29,31]$. Measurement uncertainties (2 SD) were typically below $0.2 \%$ for $\delta^{202} \mathrm{Hg}$ and below $0.1 \%$ for $\triangle^{199} \mathrm{Hg}$ and $\triangle^{200} \mathrm{Hg}$ (details in original literature). 
a)

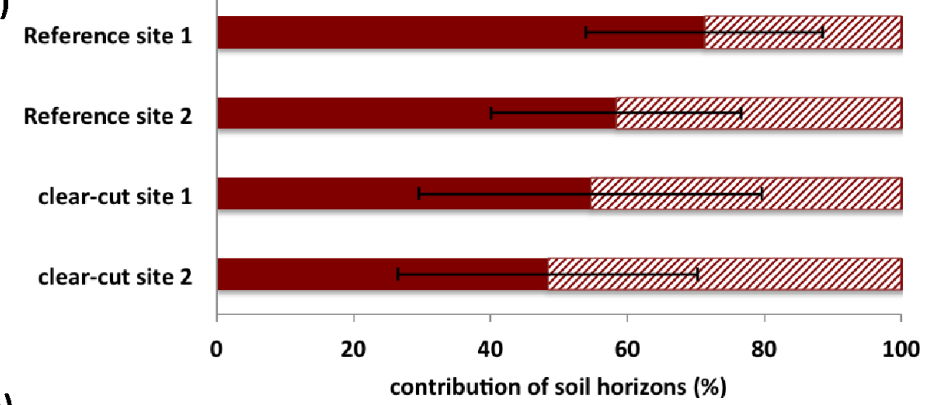

b)

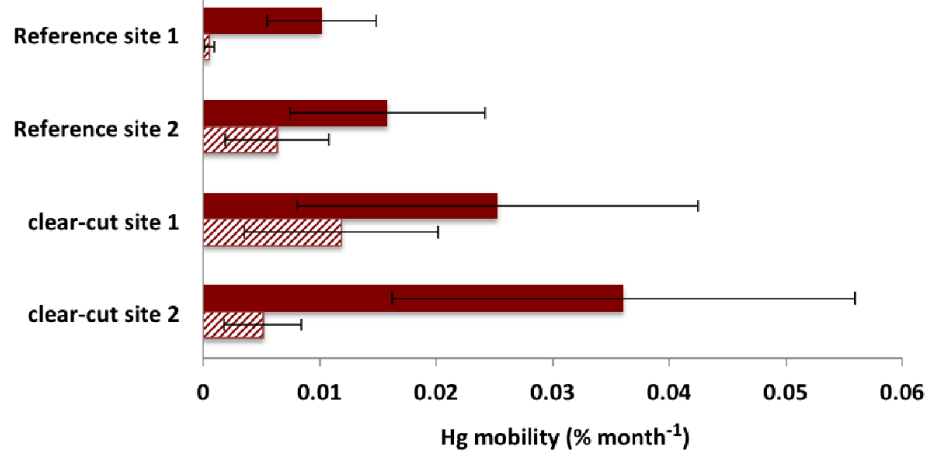

- Oe/He $\oslash \mathrm{Oa} / \mathrm{Ha}+\mathrm{E}+\mathrm{B}$

Figure 4: Role of soil horizons in catchment runoff calculated from stable $\mathrm{Hg}$ isotope signatures using a conservative mixing model (details in SI): (a) contribution of soil horizons to catchment runoff based on $\mathrm{Hg}$ isotope signatures, (b) mobility of $\mathrm{Hg}$ during moderate to high flow conditions (September 2012) relative to $\mathrm{Hg}$ pool sizes in different soil horizons. 
1

\section{References}

[1] C. T. Driscoll, R. P. Mason, H. M. Chan, D. J. Jacob, and N. Pirrone. Mercury as a global pollutant: sources, pathways, and effects. Environ. Sci. Technol., 47(10):4967-4983, 2013.

[2] J. Munthe, I. Wangberg, S. Rognerud, E. Fjeld, M. Verta, P. Porvari, and M. Meili. Mercury in nordic ecosystems. IVL Swedish Environmental Research Institute Ltd., 2007.

[3] N. V. Smith-Downey, E. M. Sunderland, and D. J. Jacob. Anthropogenic impacts on global storage and emissions of mercury from terrestrial soils: Insights from a new global model. J. Geophys. Res., 115, 2010.

[4] UNEP. Minamata convention on mercury, united nations environment programme, (http://www.mercuryconvention.org), 2013.

[5] G. A. Weyhenmeyer and J. Karlsson. Nonlinear response of dissolved organic carbon concentrations in boreal lakes to increasing temperatures. Limnol. and Oceanogr., 54(6part2):2513-2519, 2009.

[6] U. Skyllberg, P. R. Bloom, J. Qian, C. M. Lin, and W. F. Bleam. Complexation of mercury(II) in soil organic matter: EXAFS evidence for linear two-coordination with reduced sulfur groups. Environ. Sci. Technol., 40(13):4174-4180, 2006.

[7] S. Akerblom, M. Meili, L. Bringmark, K. Johansson, D. Kleja, and

B. Bergkvist. Partitioning of $\mathrm{Hg}$ between solid and dissolved organic matter in the humus layer of boreal forests. Water Air Soil Pollut., 189(1-4):239-252, 2008.

[8] J. A. Dittman, J. B. Shanley, C. T. Driscoll, G. R. Aiken, A. T. Chalmers, and J. E. Towse. Ultraviolet absorbance as a proxy for total dissolved mercury in streams. Environ. Pollut., 157(6):1953-1956, 2009.

[9] U. Skyllberg, M. B. Westin, M. Meili, and E. Bjorn. Elevated concentrations of methyl mercury in streams after forest clear-cut: A consequence 
of mobilization from soil or new methylation? Environ. Sci. Technol.,

[10] A. L. Riscassi and T. M. Scanlon. Controls on stream water dissolved mercury in three mid-Appalachian forested headwater catchments. $W a-$

[11] J. D. Demers, J. B. Yavitt, C. T. Driscoll, and M. R. Montesdeoca. Legacy mercury and stoichiometry with C, N, and S in soil, pore water, and stream water across the upland-wetland interface: The influence of hydrogeologic setting. J. Geophys. Res.-Biogeo., 118(2):825-841, 2013.

[12] C. L. Babiarz, J. P. Hurley, S. R. Hoffmann, A. W. Andren, M. M. Shafer, and D. E. Armstrong. Partitioning of total mercury and methylmercury to the colloidal phase in freshwaters. Environ. Sci. Technol., 35(24):4773-4782, 2001.

[13] R. Teisserenc, M. Lucotte, and S. Houel. Terrestrial organic matter biomarkers as tracers of $\mathrm{Hg}$ sources in lake sediments. Biogeochemistry, 103(1-3):235-244, 2011.

[14] R. Teisserenc, M. Lucotte, R. Canuel, M. Moingt, and D. Obrist. Combined dynamics of mercury and terrigenous organic matter following impoundment of Churchill falls hydroelectric reservoir, Labrador. Biogeochemistry, 118(1-3):21-34, 2014.

[15] S. Jonsson, U. Skyllberg, M. B. Nilsson, E. Lundberg, A. Andersson, and E. Bjorn. Differentiated availability of geochemical mercury pools controls methylmercury levels in estuarine sediment and biota. Nat. Commun., 5:4624, 2014.

[16] E. Garcia and R. Carignan. Impact of wildfire and clear-cutting in the boreal forest on methyl mercury in zooplankton. Can. J. Fish. Aquat. Sci., 56(2):339-345, 1999. 
[17] E. Garcia and R. Carignan. Mercury concentrations in northern pike (Esox lucius) from boreal lakes with logged, burned, or undisturbed catchments. Can. J. Fish. Aquat. Sci., 57:129-135, 2000.

[18] K. Bishop, C. Allan, L. Bringmark, E. Garcia, S. Hellsten, L. Hogbom, K. Johansson, A. Lomander, M. Meili, J. Munthe, M. Nilsson, P. Porvari, U. Skyllberg, R. Sorensen, T. Zetterberg, and S. Akerblom. The effects of forestry on $\mathrm{Hg}$ bioaccumulation in nemoral/boreal waters and recommendations for good silvicultural practice. Ambio, 38(7):373-380, 2009.

[19] K. Eklof, J. Schelker, R. Sorensen, M. Meili, H. Laudon, C. von Bromssen, and K. Bishop. Impact of forestry on total and methylmercury in surface waters: distinguishing effects of logging and site preparation. Environ. Sci. Technol., 48(9):4690-4698, 2014.

20] L. Ukonmaanaho, M. Starr, M. Kantola, A. Lauren, J. Piispanen, H. Pietilä, P. Perämäki, P. Merilä, H. Fritze, T. Tuomivirta, J. Heikkinen, J. Mäkinen, and T. M. Nieminen. Impacts of forest harvesting on mobilization of hg and mehg in drained peatland forests on black schist or felsic bedrock. Environ Mon Assess., 188(4):228, 2016.

[21] R. M. Kronberg, A. Drott, M. Jiskra, J. G. Wiederhold, E. Bjrn, and U. Skyllberg. Forest harvest contribution to Boreal freshwater methyl mercury load. Global Biogeochem. Cycles, 30(6):825-843, 2016.

[22] R. M. Kronberg, M. Jiskra, J. G. Wiederhold, E. Bjorn, and U. Skyllberg. Methyl mercury formation in hillslope soils of boreal forests: The role of forest harvest and anaerobic microbes. Environ Sci Technol, 50(17):9177-86, 2016.

[23] J. D. Blum, L. S. Sherman, and M. W. Johnson. Mercury isotopes in earth and environmental sciences. Annu. Rev. Earth Planet. Sci. Lett., 42(1):249-269, 2014.

[24] J. G. Wiederhold. Metal stable isotope signatures as tracers in environmental geochemistry. Environ. Sci. Technol., 49(5):2606-2624, 2015. 
[25] L. E. Gratz, G. J. Keeler, J. D. Blum, and L. S. Sherman. Isotopic composition and fractionation of mercury in great lakes precipitation and ambient air. Environ. Sci. Technol., 44(20):7764-7770, 2010.

[26] J-B. Chen, H. Hintelmann, X. Feng, and B. Dimock. Unusual fractionation of both odd and even mercury isotopes in precipitation from Peterborough, ON, Canada. Geochim. Cosmochim. Acta, 90(0):33-46, 2012.

[27] L. S. Sherman, J. D. Blum, G. J. Keeler, J. D. Demers, and J. T. Dvonch. Investigation of local mercury deposition from a coal-fired power plant using mercury isotopes. Environ. Sci. Technol., 46(1):382-390, 2012.

[28] P. M. Donovan, J. D. Blum, D. Yee, G. E. Gehrke, and M. B. Singer. An isotopic record of mercury in San Francisco bay sediment. Chem. Geol., 349(0):87-98, 2013.

[29] J. D. Demers, J. D. Blum, and D. R. Zak. Mercury isotopes in a forested ecosystem: Implications for air-surface exchange dynamics and the global mercury cycle. Glob. Biogeochem. Cycles, 27(1):222-238, 2013.

[30] J. D. Demers, L. S. Sherman, J. D. Blum, F. J. Marsik, and J. T. Dvonch. Coupling atmospheric mercury isotope ratios and meteorology to identify sources of mercury impacting a coastal urban-industrial region near pensacola, Florida, USA. Global Biogeochem. Cycles, 29(10):1689-1705, 2015 .

[31] M. Enrico, G. L. Roux, N. Marusczak, L. E. Heimburger, A. Claustres, X. Fu, R. Sun, and J. E. Sonke. Atmospheric mercury transfer to peat bogs dominated by gaseous elemental mercury dry deposition. Environ. Sci. Technol., 50(5):2405-12, 2016.

[32] D. Obrist, Y. Agnan, M. Jiskra, C. L. Olson, D. P. Colegrove, J. Hueber, C. W. Moore, J. E. Sonke, and D. Helmig. Tundra uptake of atmospheric elemental mercury drives arctic mercury pollution. Nature, 547(7662):201-204, 2017. 
[33] M. Jiskra, J. G. Wiederhold, U. Skyllberg, R.M. Kronberg, I. Hajdas, and R. Kretzschmar. Mercury deposition and re-emission pathways in boreal forest soils investigated with $\mathrm{Hg}$ isotope signatures. Environ. Sci. Technol., 49:7188-96, 2015.

[34] W. Zheng, D. Obrist, D. Weis, and B. A. Bergquist. Mercury isotope compositions across North American forests. Global Biogeochem. Cycles, 30(10):1475-1492, 2016.

[35] S. Lindberg, R. Bullock, R. Ebinghaus, D. Engstrom, X. Feng, W. Fitzgerald, N. Pirrone, E. Prestbo, and C. Seigneur. A synthesis of progress and uncertainties in attributing the sources of mercury in deposition. Ambio, 36(1):19-32, 2007.

[36] D. B. Senn, E. J. Chesney, J. D. Blum, M. S. Bank, A. Maage, and J. P. Shine. Stable isotope (N, C, Hg) study of methylmercury sources and trophic transfer in the northern gulf of Mexico. Environ. Sci. Technol., 44(5):1630-1637, 2010.

[37] V. Perrot, V. N. Epov, M. V. Pastukhov, V. I. Grebenshchikova, C. Zouiten, J. E. Sonke, S. Husted, O. F. X. Donard, and D. Amouroux. Tracing sources and bioaccumulation of mercury in fish of lake BaikalAngara river using $\mathrm{Hg}$ isotopic composition. Environ. Sci. Technol., 44(21):8030-8037, 2010.

[38] G. E. Gehrke, J. D. Blum, D. G. Slotton, and B. K. Greenfield. Mercury isotopes link mercury in San Francisco bay forage fish to surface sediments. Environ. Sci. Technol., 45(4):1264-1270, 2011.

[39] S. Y. Kwon, J. D. Blum, C. Y. Chen, D. E. Meattey, and R. P. Mason. Mercury isotope study of sources and exposure pathways of methylmercury in estuarine food webs in the northeastern U.S. Environ Sci Technol, 48(17):10089-97, 2014.

[40] M. T. Tsui, J. D. Blum, S. Y. Kwon, J. C. Finlay, S. J. Balogh, and Y. H. Nollet. Sources and transfers of methylmercury in adjacent river and forest food webs. Environ. Sci. Technol., 46(20):10957-64, 2012. 
[41] M. T. Tsui, J. D. Blum, J. C. Finlay, S. J. Balogh, Y. H. Nollet, W. J.

[49] IUSS Working Group WRB. World Reference Base for Soil Resources 2014, update 2015 International soil classification system for naming 
soils and creating legends for soil maps. World Soil Resources Reports No. 106. FAO, Rome. 2015.

[50] U. Skyllberg, J. Qian, W. Frech, K. Xia, and W. F. Bleam. Distribution of mercury, methyl mercury and organic sulphur species in soil, soil solution and stream of a boreal forest catchment. Biogeochemistry, 64(1):53-76, 2003.

[51] V. Liem-Nguyen, U. Skyllberg, and E. Bjorn. Thermodynamic modeling of the solubility and chemical speciation of mercury and methylmercury driven by organic thiols and micromolar sulfide concentrations in boreal wetland soils. Environ Sci Technol, 51(7):3678-3686, 2017.

[52] A. Deonarine and H. Hsu-Kim. Precipitation of mercuric sulfide nanoparticles in nom-containing water: Implications for the natural environment. Environ. Sci. Technol., 43(7):2368-2373, 2009.

[53] J. G. Wiederhold, C. J. Cramer, K. Daniel, I. Infante, B. Bourdon, and R. Kretzschmar. Equilibrium mercury isotope fractionation between dissolved $\mathrm{Hg}(\mathrm{II})$ species and thiol-bound Hg. Environ. Sci. Technol., 44(11):4191-4197, 2010.

[54] M. Jiskra, J. G. Wiederhold, B. Bourdon, and R. Kretzschmar. Solution speciation controls mercury isotope fractionation of $\mathrm{Hg}$ (II) sorption to goethite. Environ. Sci. Technol., 46(12):6654-62, 2012.

[55] J. Blum and B. Bergquist. Reporting of variations in the natural isotopic composition of mercury. Anal. Bioanal. Chem., 388(2):353-359, 2007.

[56] T. B. Coplen. Guidelines and recommended terms for expression of stable-isotope-ratio and gas-ratio measurement results. Rapid Commun. Mass Spectrom., 25(17):2538-2560, 2011.

[57] N. Estrade, J. Carignan, J. E. Sonke, and O. F. X. Donard. Mercury isotope fractionation during liquid-vapor evaporation experiments. Geochim. Cosmochim. Acta, 73(10):2693-2711, 2009. 
[58] J. G. Wiederhold, R. S. Smith, H. Siebner, A. D. Jew, Jr. Brown, G. E., B. Bourdon, and R. Kretzschmar. Mercury isotope signatures as tracers for $\mathrm{Hg}$ cycling at the New Idria $\mathrm{Hg}$ mine. Environ. Sci. Technol., 47(12):6137-45, 2013.

[59] R. S. Smith, J. G. Wiederhold, A. D. Jew, G. E. Brown Jr, B. Bourdon, and R. Kretzschmar. Small-scale studies of roasted ore waste reveal extreme ranges of stable mercury isotope signatures. Geochim. Cosmochim. Acta, 137(0):1-17, 2014.

[61] R. S. Smith, J. G. Wiederhold, A. D. Jew, G. E. Brown, B. Bourdon, and R. Kretzschmar. Stable Hg isotope signatures in creek sediments impacted by a former Hg mine. Environ. Sci. Technol., 49(2):767-776, 2015.

[62] L. Wacker, G. Bonani, M. Friedrich, I. Hajdas, B. Kromer, M. Nemec, M. Ruff, M. Suter, H. A. Synal, and C. Vockenhuber. Micadas: routine and high-precision radiocarbon dating. Radiocarbon, 52(2):252-262, 2010 .

[63] P. J. Reimer, T. A. Brown, and R. W. Reimer. Discussion: Reporting and calibration of post-bomb C-14 data. Radiocarbon, 46(3):1299-1304, 2004 .

${ }_{822}^{6}$ [64] A. Biswas, J. D. Blum, B. A. Bergquist, G. J. Keeler, and Z. Q. Xie. Natural mercury isotope variation in coal deposits and organic soils. Environ. Sci. Technol., 42(22):8303-8309, 2008.

[65] H. Zhang, R. S. Yin, X. B. Feng, J. Sommar, C. W. Anderson, A. Sapkota, X. W. Fu, and T. Larssen. Atmospheric mercury inputs in montane soils increase with elevation: evidence from mercury isotope signatures. 
1

2

3

4

5

6

[66] X. Fu, N. Marusczak, X. Wang, F. Gheusi, and J. E. Sonke. Isotopic composition of gaseous elemental mercury in the free troposphere of the Pic du Midi observatory, France. Environ Sci Technol, 50(11):5641-50, 2016.

[67] R. Yin, X. Feng, and B. Meng. Stable mercury isotope variation in rice plants (oryza sativa 1.) from the wanshan mercury mining district, sw china. Environ Sci Technol, 47(5):2238-45, 2013.

[68] R. F. Lepak, R. Yin, D. P. Krabbenhoft, J. M. Ogorek, J. F. DeWild, T. M. Holsen, and J. P. Hurley. Use of stable isotope signatures to determine mercury sources in the great lakes. Environ Sci Technol Let, 2(12):335-341, 2015.

[69] K. Bishop, J. Seibert, S. Koher, and H. Laudon. Resolving the double paradox of rapidly mobilized old water with highly variable responses in runoff chemistry. Hydrol. Process., 18(1):185-189, 2004.

[70] M. Jiskra, D. Saile, J. G. Wiederhold, B. Bourdon, E. Bjorn, and R. Kretzschmar. Kinetics of $\mathrm{Hg}$ (II) exchange between organic ligands, goethite, and natural organic matter studied with an enriched stable isotope approach. Environ. Sci. Technol., 48:13207-13217, 2014.

[71] B. A. Bergquist and J. D. Blum. Mass-dependent and -independent fractionation of $\mathrm{Hg}$ isotopes by photoreduction in aquatic systems. Science, 318(5849):417-420, 2007.

[72] K. Kritee, J. D. Blum, M. W. Johnson, B. A. Bergquist, and T. Barkay. Mercury stable isotope fractionation during reduction of $\mathrm{Hg}$ (II) to ${ }_{852} \mathrm{Hg}(0)$ by mercury resistant microorganisms. Environ. Sci. Technol., 41(6):1889-1895, 2007.

[73] W. Zheng and H. Hintelmann. Nuclear field shift effect in isotope fractionation of mercury during abiotic reduction in the absence of light. $J$. Phys. Chem. A, 114(12):4238-4245, 2010. 
[74] M. Froberg, D. Berggren, B. Bergkvist, C. Bryant, and H. Knicker. Contributions of Oi, Oe and Oa horizons to dissolved organic matter in forest floor leachates. Geoderma, 113(3-4):311-322, 2003.

[75] M. Froberg, D. Berggren, B. Bergkvist, C. Bryant, and J. Mulder. Concentration and fluxes of dissolved organic carbon (DOC) in three norway spruce stands along a climatic gradient in Sweden. Biogeochemistry, $77(1): 1-23,2006$.

[76] S. L. Schiff, R. Aravena, S. E. Trumbore, M. J. Hinton, R. Elgood, and P. J. Dillon. Export of DOC from forested catchments on the precambrian shield of central Ontario: Clues from C-13 and C-14. Biogeochemistry, 36(1):43-65, 1997.

[77] S. M. Palmer, D. Hope, M. F. Billett, J. J. C. Dawson, and C. L. Bryant. Sources of organic and inorganic carbon in a headwater stream: Evidence from carbon isotope studies. Biogeochemistry, 52(3):321-338, 2001.

[78] C. J. Hulatt, H. Kaartokallio, M. J. Oinonen, E. Sonninen, C. A. Stedmon, and D. N. Thomas. Radiocarbon dating of fluvial organic matter reveals land-use impacts in boreal peatlands. Environ. Sci. Technol., 48(21):12543-51, 2014.

[79] D. Obrist, D. W. Johnson, and S. E. Lindberg. Mercury concentrations and pools in four Sierra Nevada forest sites, and relationships to organic carbon and nitrogen. Biogeosciences, 6(5):765-777, 2009.

[80] D. Obrist, D. W. Johnson, S. E. Lindberg, Y. Luo, O. Hararuk, R. Bracho, J. J. Battles, D. B. Dail, R. L. Edmonds, R. K. Monson, S. V. Ollinger, S. G. Pallardy, K. S. Pregitzer, and D. E. Todd. Mercury distribution across 14 US forests. Part I: Spatial patterns of concentrations in biomass, litter, and soils. Environ. Sci. Technol., 45(9):3974-3981, 2011. 
885

891

[83] C. J. Oswald and B. A. Branfireun. Antecedent moisture conditions control mercury and dissolved organic carbon concentration dynamics

894 
912

915

[90] J. Schelker, T. Grabs, K. Bishop, and H. Laudon. Drivers of increased organic carbon concentrations in stream water following forest disturbance: Separating effects of changes in flow pathways and soil warming. J. Geophys. Res.-Biogeosci., 118(4):002309, 2013.

[91] D. E. Butman, H. F. Wilson, R. T. Barnes, M. A. Xenopoulos, and P. A. Raymond. Increased mobilization of aged carbon to rivers by human disturbance. Nature Geosci., 8(2):112-116, 2015.

[92] J. A. Fisher, D. J. Jacob, A. L. Soerensen, H. M. Amos, A. Steffen, and E. M. Sunderland. Riverine source of arctic ocean mercury inferred from atmospheric observations. Nat. Geosci., 5(7):499-504, 2012.

[93] H. M. Amos, D. J. Jacob, D. Kocman, H. M. Horowitz, Y. Zhang, S. Dutkiewicz, M. Horvat, E. S. Corbitt, D. P. Krabbenhoft, and E. M. Sunderland. Global biogeochemical implications of mercury discharges from rivers and sediment burial. Environ Sci Technol, 48(16):9514-22, 2014.

[94] X. Wang, J. Luo, R. Yin, W. Yuan, C. J. Lin, J. Sommar, X. Feng, H. Wang, and C. Lin. Using mercury isotopes to understand mercury accumulation in the montane forest floor of the eastern tibetan plateau. Environ Sci Technol, 2016.

[95] M. Li, A. T. Schartup, A. P. Valberg, J. D. Ewald, D. P. Krabbenhoft, R. Yin, P. H. Balcom, and E. M. Sunderland. Environmental origins of methylmercury accumulated in subarctic estuarine fish indicated by mercury stable isotopes. Environ Sci Technol, 50(21):11559-11568, 2016.

[96] S. E. Grasby, W. Shen, R. Yin, J. D. Gleason, J. D. Blum, R. F. Lepak, J. P. Hurley, and B. Beauchamp. Isotopic signatures of mercury contamination in latest permian oceans. Geology, 45(1):55-58, 2016.

[97] J. D. Gleason, J. D. Blum, T. C. Moore, L. Polyak, M. Jakobsson, P. A. Meyers, and A. Biswas. Sources and cycling of mercury in the paleo Arctic Ocean from $\mathrm{Hg}$ stable isotope variations in Eocene and Quaternary sediments. Geochim Cosmochim Acta, 197:245-262, 2017. 
1

2

3

4

5

6

7

8

9

\title{
Electronic Supplementary Information (ESI)
}

to

\section{Source tracing of natural organic} matter bound mercury in boreal forest runoff with mercury stable isotopes

\author{
Martin Jiskra*,1,2,3, Jan G. Wiederhold*,1,2,4 Ulf Skyllberg $^{5}$, \\ Rose-Marie Kronberg ${ }^{5}$, and Ruben Kretzschmar ${ }^{1}$
}

July 29, 2017

\footnotetext{
${ }^{1}$ Soil Chemistry, Institute of Biogeochemistry and Pollutant Dynamics (IBP), ETH Zurich, CHN, CH-8092 Zurich, Switzerland

${ }^{2}$ Isotope Geochemistry, Institute of Geochemistry and Petrology (IGP), ETH

Zurich, CH-8092 Zurich, Switzerland

${ }^{3}$ Observatoire Midi-Pyrénées, Laboratoire Géosciences Environnement Toulouse (GET), CNRS-IRD-Université de Toulouse, F-31400 Toulouse, France ${ }^{4}$ Department of Environmental Geosciences, University of Vienna, A-1090 Vienna, Austria

${ }^{5}$ Department of Forest Ecology and Management, Swedish University of Agricultural Sciences, S-90183 Umeå, Sweden

*martin.jiskra@gmail.com, jan.wiederhold@univie.ac.at
} 


\section{Contents}

\section{List of Figures}

S1 Map of water sampling sites . . . . . . . . . . . . . . 3

S2 Precipitation and $\mathrm{Hg} / \mathrm{C}$ ratios over sampling period . . . . . . 4

S3 $\mathrm{Hg} / \mathrm{C}$ ratios of boreal forest sites . . . . . . . . . . 5

S4 Precipitation at Junsele SMHI station during September 20125

S5 Comparison of radiocarbon signatures from bulk soils and humic acid extracts . . . . . . . . . . . . . . 6

\section{List of Tables}

S1 Concentration data of soil samples from clear-cut sites $\ldots .7$

S2 Concentration data of soil samples from reference sites . . . . 8

S3 $\mathrm{Hg}$ isotope data of soil samples from reference sites . . . . . 9

S4 Compilation of $\mathrm{Hg}$ isotope signatures, radiocarbon signatures and $\mathrm{Hg} / \mathrm{C}$ ratios . . . . . . . . . . . . . . . . . 11

S5 Hg pool size and annual outflow of borel forest catchments . . 12

S6 Results of mixing models . . . . . . . . . . . . . . . . 13

S7 Results of ultrafiltration pre-enrichments . . . . . . . . . 13

S8 Model results of precipitation-derived $\mathrm{Hg}$ in runoff samples . . 14

S9 $\mathrm{Hg}$ isotope results of standards . . . . . . . . . . . 15 
1

2

3

4

5

6

7

8
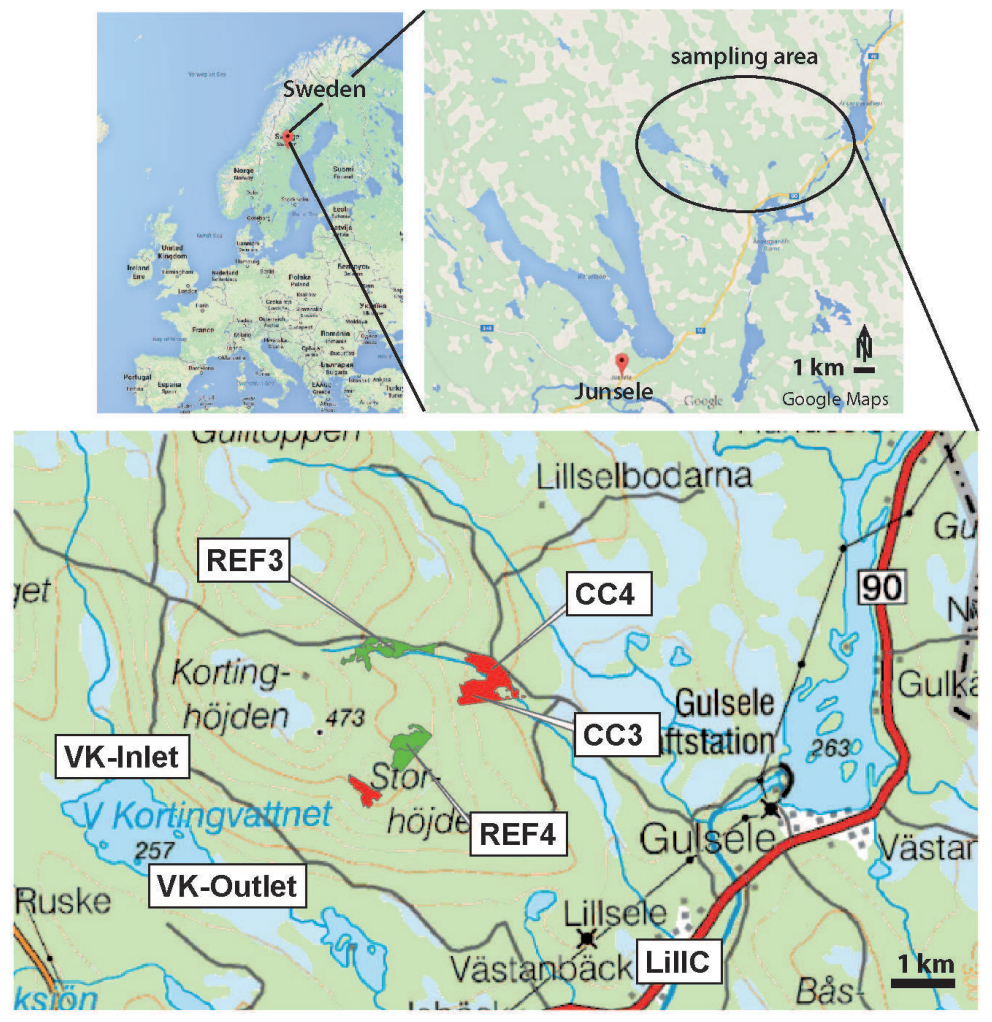

Figure S1: Map of water sampling sites. The different water sampling locations are indicated at the lower panel. The four boreal forest catchments (reference site 1 and 2 in green and clear-cut site 1 and 2 in red) drain in the same Lillsele stream. 

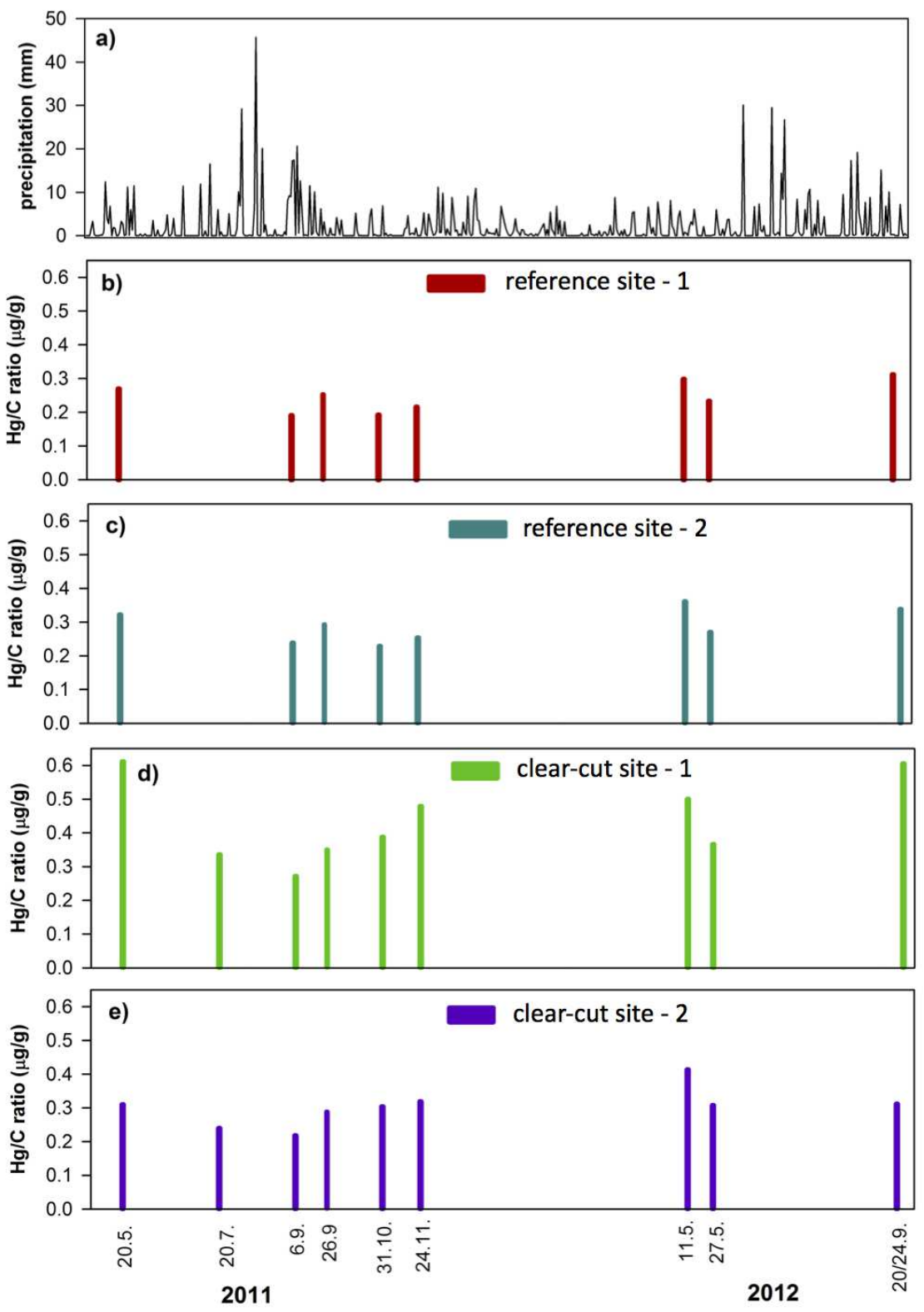

Figure S2: a) Precipitation at Junsele SMHI over whole sampling campaign from Mai 2011 to September 2012 (Data from Swedish Meterological Institute, $\mathrm{SMHI}) \mathrm{Hg} / \mathrm{C}$ ratios of the four sites: $\mathbf{b}$ ) reference site $-1, \mathbf{c})$ reference site - 2, d) clear-cut site 1, and d) clear-cut site 2. (Data from Kronberg [1], $[2])$. 
1

2

3

4

5

6

7

8

b)
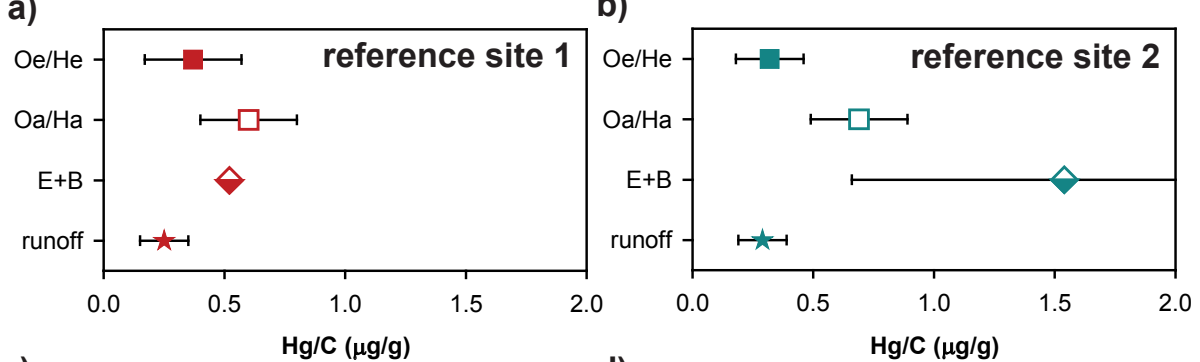

c)

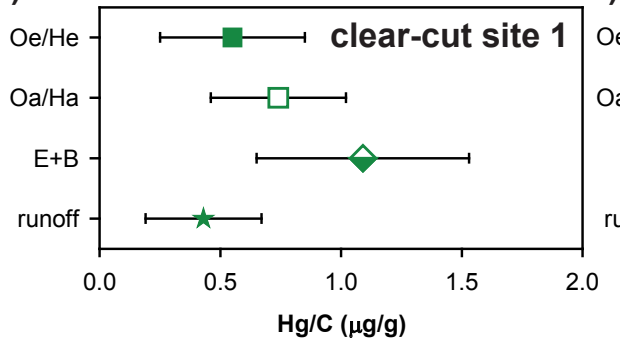

d)

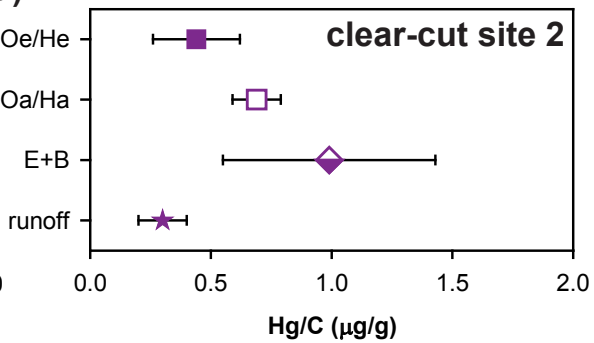

Figure S3: $\mathrm{Hg} / \mathrm{C}$ ratios of boreal forest sites: The symbols represent the average and the error bars 2 standard deviation of the measured values.

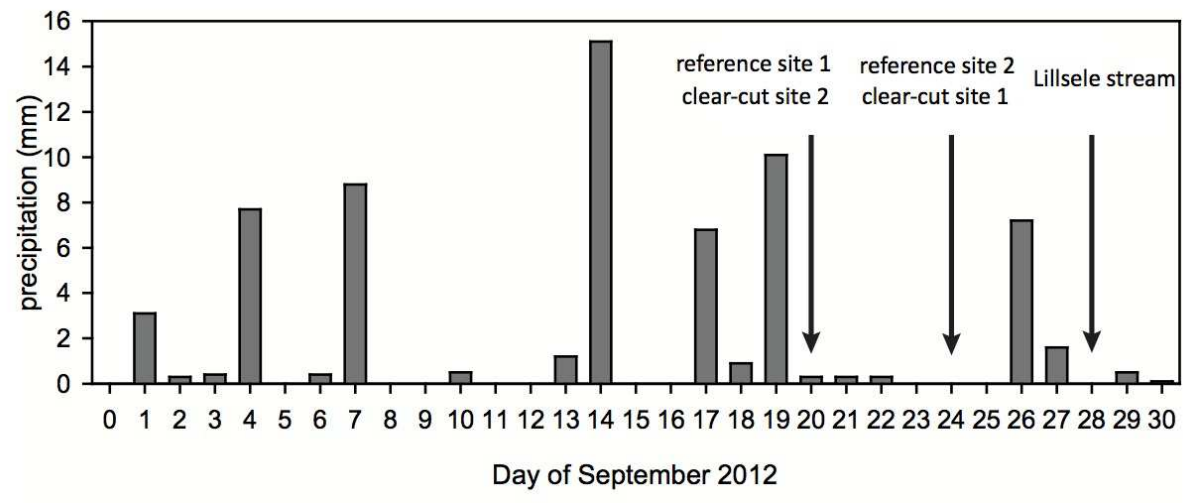

Figure S4: Precipitation at Junsele SMHI station during September 2012 (Data from Swedish Meterological Institute, SMHI). The arrows indicate the days of sampling. 


\section{Radiocarbon dating}

In addition to the radiocarbon dating of the bulk soil samples we performed humic acid extractions of a selection of samples. We followed an extraction procedure for the humic acid fraction adapted from the International Humic Substances Society (IHSS)[3]. $10 \mathrm{~g}$ of soil sample was added to $100 \mathrm{ml} 0.1 \mathrm{M}$ $\mathrm{HCl}$ and shaken on a horizontal shaker for 1 h. Then $\mathrm{pH}$ was adjusted to 7 with $1 \mathrm{M} \mathrm{NaOH}$ and $0.1 \mathrm{M} \mathrm{NaOH}$ was added to reach a solid to solution ratio of 1:10. The soil samples were shaken for $4.5 \mathrm{~h}$ followed by sedimentation over night under $\mathrm{N}_{2}$ atmosphere. The samples were centrifuged at $1000 \mathrm{rpm}$ for $12 \mathrm{~min}$ and the humic acid extract decanted. The humic acid extract was then freeze-dried for radiocarbon analysis.

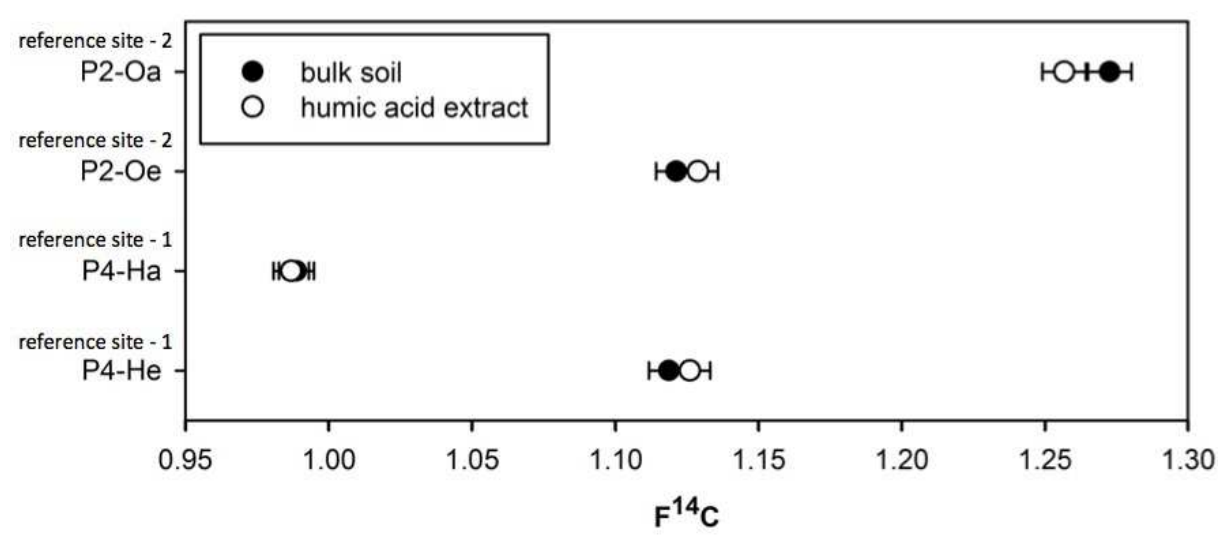

Figure S5: Comparison of radiocarbon signatures from bulk soils and humic acid extracts: The error bars represent two standard deviations of the analytical precision. 
1

2

3

4

5

6

7

8

9

10

11

12

13

14

15

16

17

18

19

20

21

22

23

24

25

26

27

28

29

30

31

32

33

34

35

36

37

38

39

40

41

42

43

44

45

46

47

48

49

50

51

52

53

54

55

56

57

58

59

60

Table S1: Concentration data of soil samples from clear-cut sites: Horizon thickness, total $\mathrm{Hg}$ concentration ( $\mathrm{Hg}$ tot), carbon $(\mathrm{C})$ and nitrogen $(\mathrm{N})$ concentration (\% weight), $\mathrm{C} / \mathrm{N}$ ratio, $\mathrm{Hg} / \mathrm{C}$ ratio, Si concentration, distance from first-order stream (distance), and height of groundwater table (GWT) below surface during the soil sampling campaign in 2011. Distance and GWT are reproduced from Kronberg et al. [1][2].

\begin{tabular}{|c|c|c|c|c|c|c|c|c|c|}
\hline Sample & $\begin{array}{l}\text { horizon } \\
\text { (cm) }\end{array}$ & $\begin{array}{l}\text { Hg tot } \\
\left(n g g^{-1}\right)\end{array}$ & $\begin{array}{c}\mathrm{C} \\
(\%)\end{array}$ & $\begin{array}{c}\mathrm{N} \\
(\%)\end{array}$ & $\begin{array}{c}\mathrm{C} / \mathrm{N} \\
\left(\mathrm{g} \mathrm{g}^{-1}\right)\end{array}$ & $\begin{array}{c}\mathrm{Hg} / \mathrm{C} \\
\left(\mu \mathrm{g} \mathrm{g}{ }^{-1}\right)\end{array}$ & $\begin{array}{c}\mathrm{Si} \\
\left(\mathrm{mg} \mathrm{g}^{-1}\right)\end{array}$ & $\begin{array}{c}\text { distance } \\
(\mathrm{m})\end{array}$ & $\begin{array}{l}\text { GWT } \\
(\mathrm{cm})\end{array}$ \\
\hline \multicolumn{10}{|c|}{ clear-cut site - 1} \\
\hline P1-He & 4 & 378 & 39.9 & 1.7 & 26.6 & 0.95 & 24 & 1 & 0 \\
\hline $\mathrm{P} 2-\mathrm{He}$ & 4 & 164 & 43.6 & 1.3 & 38.4 & 0.38 & 9 & 12 & 6 \\
\hline P3-Oe & 8 & 107 & 43.0 & 0.9 & 56.7 & 0.25 & 6 & 24 & 34 \\
\hline P4-Oe & 5 & 143 & 37.6 & 1.1 & 39.4 & 0.38 & 19 & 51 & 25 \\
\hline P5-Oe & 9 & 312 & 40.3 & 1.3 & 36.0 & 0.77 & 18 & 72 & $>50$ \\
\hline P1-Ha & 23 & 340 & 32.3 & 1.3 & 28.3 & 1.05 & 48 & 1 & 0 \\
\hline P2-Ha & 30 & 262 & 29.2 & 1.3 & 26.6 & 0.90 & 77 & 12 & 6 \\
\hline P3-Oa & 4 & 216 & 45.7 & 1.1 & 49.4 & 0.47 & 7 & 24 & 34 \\
\hline $\mathrm{P} 4-\mathrm{Oa}$ & 8 & 182 & 33.1 & 1.4 & 27.0 & 0.55 & 40 & 51 & 25 \\
\hline P5-E & 3 & 18 & 1.9 & $<0.1$ & 104.9 & 0.93 & 262 & 72 & $>50$ \\
\hline P5-B & nd & 60 & 4.8 & 0.1 & 51.3 & 1.25 & 178 & 72 & $>50$ \\
\hline \multicolumn{10}{|c|}{ clear-cut site - 2} \\
\hline P1-He & 7 & 235 & 42.9 & 1.6 & 31.4 & 0.55 & 11 & 1 & 34 \\
\hline $\mathrm{P} 2-\mathrm{He}$ & 6 & 246 & 50.1 & 1.5 & 40.1 & 0.49 & 8 & 6 & 29 \\
\hline P3-He & 5 & 176 & 46.2 & 1.3 & 42.0 & 0.38 & 6 & 10 & 12 \\
\hline P4-He & 7 & 137 & 43.7 & 1.3 & 39.5 & 0.31 & 5 & 22 & 10 \\
\hline P5-Oe & 4 & 199 & 41.8 & 1.3 & 37.2 & 0.48 & 12 & 13 & $>40$ \\
\hline P1-Ha & 30 & 220 & 31.3 & 1.6 & 22.2 & 0.70 & 34 & 1 & 34 \\
\hline P2-Ha & 25 & 278 & 40.3 & 1.8 & 25.9 & 0.69 & 19 & 6 & 29 \\
\hline P3-Ha & 35 & 260 & 38.0 & 1.8 & 24.6 & 0.69 & 18 & 10 & 12 \\
\hline P4-Ha & 24 & 213 & 34.2 & 1.8 & 22.5 & 0.62 & 29 & 22 & 10 \\
\hline P5-Oa & 3 & 273 & 36.4 & 1.0 & 41.8 & 0.75 & 22 & 13 & $>40$ \\
\hline P5-E & 7 & 11 & 0.8 & $<0.1$ & nd & 1.26 & 271 & 13 & $>40$ \\
\hline P5-B & nd & 15 & 2.0 & $<0.1$ & nd & 0.72 & 211 & 13 & $>40$ \\
\hline
\end{tabular}


Table S2: Concentration data of soil samples from reference sites: Horizon thickness, total $\mathrm{Hg}$ concentration ( $\mathrm{Hg}$ tot), carbon $(\mathrm{C})$ and nitrogen $(\mathrm{N})$ concentration (\% weight), $\mathrm{C} / \mathrm{N}$ ratio, $\mathrm{Hg} / \mathrm{C}$ ratio, Si concentration, distance from first-order stream (distance), and height of groundwater table (GWT) below surface during the soil sampling campaign in 2011. The concentration data are reproduced from Jiskra et al. [4] and distance and GWT are reproduced from Kronberg et al.[1], [2].

\begin{tabular}{llllllll}
\hline Sample horizon & $\mathrm{Hg}$ tot & $\mathrm{C}$ & $\mathrm{N}$ & $\mathrm{C} / \mathrm{N}$ & $\mathrm{Hg} / \mathrm{C}$ & $\mathrm{Si}$ & Distance $\mathrm{GWT}$
\end{tabular}

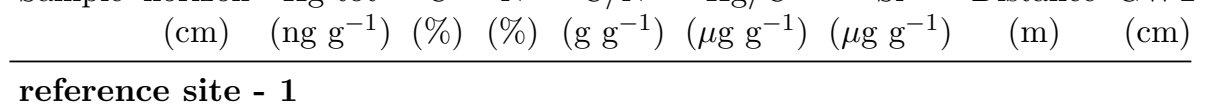

\begin{tabular}{lccccccccc} 
P1-He & 5 & 180 & 39 & 1.90 & 20.5 & 465 & 3428 & 1 & 80 \\
P2-He & 10 & 209 & 45 & 1.92 & 23.5 & 464 & 3861 & 5 & 38 \\
P3-He & 8 & 171 & 43 & 1.74 & 24.7 & 397 & 3335 & 12 & 38 \\
P4-He & 10 & 131 & 52 & 1.59 & 32.7 & 252 & 2639 & 21 & 12 \\
P5-Oe & 5 & 121 & 43 & 1.00 & 42.4 & 284 & 5582 & 29 & $>50$ \\
P1-Ha & 68 & 255 & 44 & 1.92 & 22.9 & 578 & 26720 & 1 & 80 \\
P2-Ha & 68 & 307 & 41 & 1.82 & 22.7 & 744 & 30020 & 5 & 38 \\
P3-Ha & 40 & 225 & 43 & 2.21 & 19.4 & 526 & 14750 & 13 & 38 \\
P4-Ha & 45 & 240 & 43 & 2.21 & 19.4 & 561 & 7662 & 21 & 12 \\
\hline reference site -2 & 2 & & & & & & & \\
P1-Oe & 10 & 91 & 40 & 0.53 & 75.9 & 229 & 4539 & 1 & 44 \\
P2-Oe & 10 & 160 & 51 & 1.01 & 51.0 & 311 & 9977 & 6 & $>40$ \\
P3-Oe & 6 & 163 & 39 & 1.03 & 38.4 & 414 & 12210 & 14 & $>40$ \\
P4-Oe & 4 & 147 & 45 & 1.01 & 44.1 & 329 & 11100 & 29 & $>40$ \\
P5-Oe & 6 & 155 & 47 & 1.03 & 45.5 & 332 & 7340 & 34 & $>40$ \\
P1-Oa & 2 & 188 & 29 & 0.65 & 44.5 & 646 & 74810 & 1 & $>40$ \\
P2-Oa & 2 & 258 & 45 & 0.84 & 53.5 & 577 & 19680 & 6 & $>40$ \\
P3-Oa & 2 & 313 & 38 & 0.91 & 42.3 & 815 & 16740 & 14 & $>40$ \\
P4-Oa & 2 & 299 & 39 & 0.97 & 39.7 & 773 & 21020 & 29 & $>40$ \\
P5-Oa & 2 & 247 & 40 & 0.94 & 42.8 & 616 & 41040 & 34 & $>40$ \\
\hline nd= not determined & & & & & & & &
\end{tabular}

nd $=$ not determined 


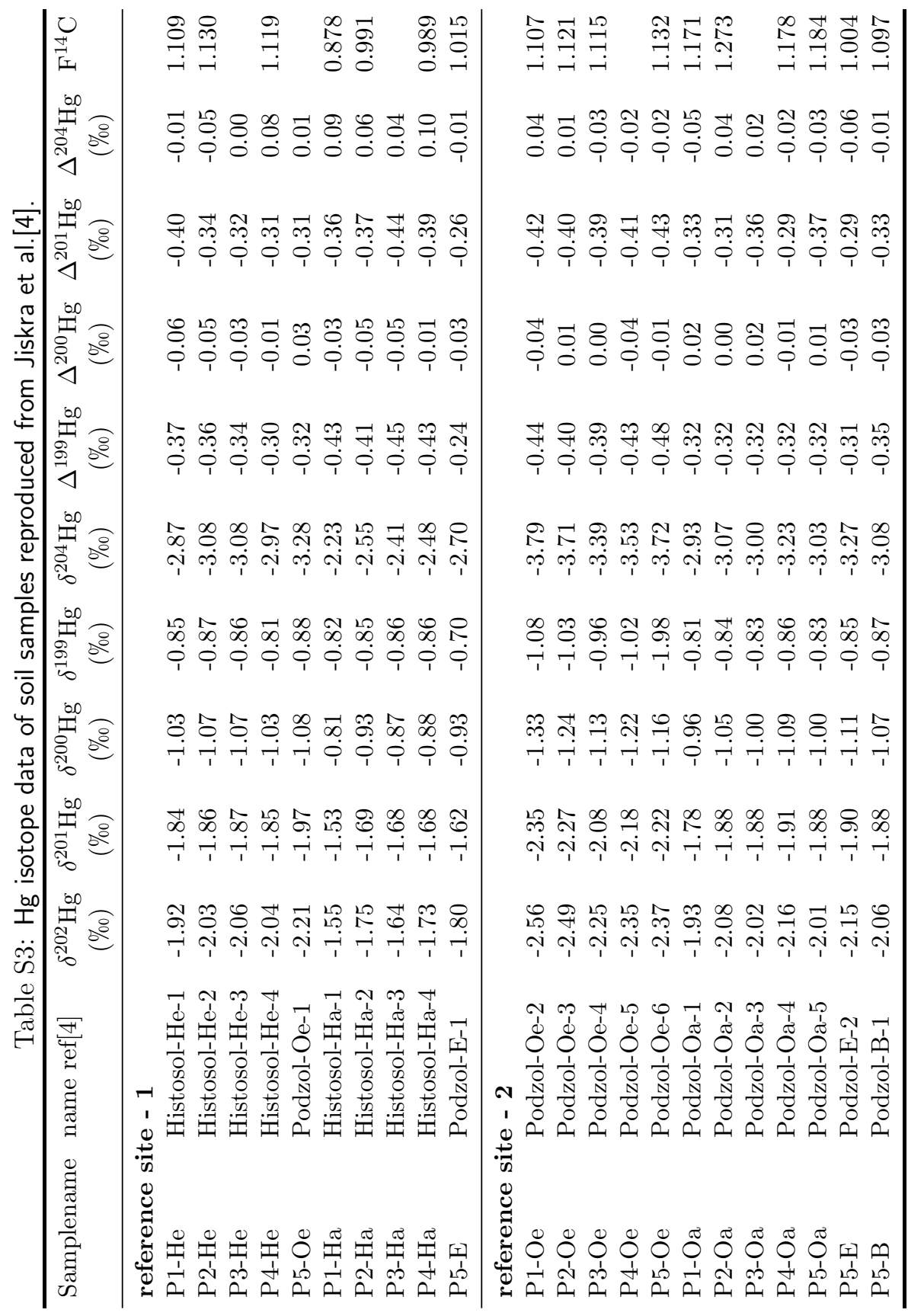




\section{Mixing model}

To model the endmembers of the different soil horizons we used the average and variance of the measured results. The results of the $\mathrm{Hg}$ isotope signatures, radiocarbon signatures and $\mathrm{Hg} / \mathrm{C}$ ratios are provided in Table $\mathrm{S} 4$. For soil horizons with only one measurement we used the standard deviation of the analytical precision to estimate the variance on the soil horizon. For the $\mathrm{Hg}$ isotope mixing a two-dimensional model combining $\mathrm{MDF}\left(\delta^{202} \mathrm{Hg}\right)$ and $\operatorname{MIF}\left(\Delta^{199}\right)$ signatures was used as follows:

$$
\begin{aligned}
& \delta^{202} \mathrm{Hg}_{\text {mixed }}=f_{\mathrm{Oe} / \mathrm{He}} \times \delta^{202} \mathrm{Hg}_{\mathrm{Oe} / \mathrm{He}}+f_{\mathrm{Oa} / \mathrm{Ha}} \times \delta^{202} \mathrm{Hg}_{\mathrm{Oa} / \mathrm{Ha}}+f_{\mathrm{E}+\mathrm{B}} \times \delta^{202} \mathrm{Hg}_{\mathrm{E}+\mathrm{B}} \\
& \Delta^{199} \mathrm{Hg}_{\text {mixed }}=f_{\mathrm{Oe} / \mathrm{He}} \times \Delta^{199} \mathrm{Hg}_{\mathrm{Oe} / \mathrm{He}}+f_{\mathrm{Oa} / \mathrm{Ha}} \times \Delta^{199} \mathrm{Hg}_{\mathrm{Oa} / \mathrm{Ha}}+f_{\mathrm{E}+\mathrm{B}} \times \Delta^{199} \mathrm{Hg}_{\mathrm{E}+\mathrm{B}}
\end{aligned}
$$

where $f_{\mathrm{Oe} / \mathrm{He}}, f_{\mathrm{Oa} / \mathrm{Ha}}$, and $f_{\mathrm{E}+\mathrm{B}}$ correspond to the fraction of $\mathrm{Hg}$ or $\mathrm{C}$ from the $\mathrm{Oe} / \mathrm{He}, \mathrm{Oa} / \mathrm{Ha}$, and $\mathrm{E}+\mathrm{B}$ horizon, respectively. The fractions of the different soil horizons were simulated using the linear distributed pseudorandom number generation function and the tracer signatures were simulated using the normal distributed pseudorandom number generation function of Matlab (R2012a, MathWorks). The results from the model simulations were compared to the measured values in the runoff and the average and standard deviation $(\sigma)$ of model simulations in agreement with the measured values are reported. Based on the fact that the $\mathrm{Hg}$ isotope signatures of the $\mathrm{Oa} / \mathrm{Ha}$ horizons and the $\mathrm{E}+\mathrm{B}$ horizons are statistically not significantly different, the fraction of the $\mathrm{Oa} / \mathrm{Ha}$ horizons and the $\mathrm{E}+\mathrm{B}$ horizons are summed up and reported in the manuscript as fraction $\mathrm{Oa} / \mathrm{Ha}+\mathrm{E}+\mathrm{B}$. 
1

2

3

4

5

6

7

8

9

10

11

12

13

14

15

16

17

18

19

20

21

22

23

24

25

26

27

28

29

30

31

32

33

34

35

36

37

38

39

40

41

42

43

44

45

46

47

48

49

50

51

52

53

54

55

56

57

58

59

60

Table S4: Compilation of $\mathrm{Hg}$ isotope signatures, radiocarbon signatures and $\mathrm{Hg} / \mathrm{C}$ ratios of different soil horizons and boreal forest catchment runoff. The average and standard deviation of the measured $\mathrm{Hg}$ isotope data were used to describe the source components in the mixing models.

\begin{tabular}{|c|c|c|c|c|c|c|c|c|c|c|c|c|}
\hline \multirow[t]{2}{*}{ Site } & \multicolumn{3}{|c|}{$\delta^{202} \mathbf{H g}$} & \multicolumn{3}{|c|}{$\Delta^{199} \mathbf{H g}$} & \multicolumn{2}{|c|}{$\mathbf{F}^{14} \mathbf{C}$} & \multicolumn{3}{|c|}{$\mathrm{Hg} / \mathrm{C}$} & \multirow[b]{2}{*}{$\begin{array}{c}\sigma \\
\left(\mu \mathrm{g} \mathrm{g}^{-1}\right)\end{array}$} \\
\hline & $\mathrm{n}$ & $\begin{array}{c}\text { average } \\
(\% 0)\end{array}$ & $\begin{array}{c}\sigma \\
(\%)\end{array}$ & $\mathrm{n}$ & $\begin{array}{c}\text { average } \\
(\%))\end{array}$ & $\begin{array}{c}\sigma \\
(\%)\end{array}$ & $\mathrm{n}$ & average & $\sigma$ & $\mathrm{n}$ & $\begin{array}{l}\text { average } \\
\left(\mu \mathrm{g} \mathrm{g}^{-1}\right)\end{array}$ & \\
\hline \multicolumn{13}{|c|}{ reference site - 1} \\
\hline $\mathrm{Oe} / \mathrm{He}$ & 5 & -2.05 & 0.10 & 5 & -0.34 & 0.03 & 3 & 1.12 & 0.01 & 5 & 0.37 & 0.10 \\
\hline $\mathrm{Oa} / \mathrm{Ha}$ & 4 & -1.67 & 0.09 & 4 & -0.43 & 0.02 & 3 & 0.95 & 0.06 & 4 & 0.60 & 0.10 \\
\hline $\mathrm{E}$ & 1 & -1.80 & & 1 & -0.24 & & 1 & 1.02 & & 1 & 0.52 & \\
\hline runoff & 1 & -1.99 & & 1 & -0.33 & & 1 & 1.10 & & 8 & 0.25 & 0.05 \\
\hline \multicolumn{13}{|c|}{ reference site -2} \\
\hline Oe & 5 & -2.41 & 0.12 & 5 & -0.43 & 0.04 & 4 & 1.12 & 0.01 & 5 & 0.32 & 0.07 \\
\hline $\mathrm{Oa}$ & 5 & -2.04 & 0.08 & 5 & -0.32 & 0.00 & 4 & 1.20 & 0.05 & 5 & 0.69 & 0.10 \\
\hline $\mathrm{E} / \mathrm{B}$ & 2 & -2.10 & 0.06 & 2 & -0.33 & 0.03 & 2 & 1.05 & 0.07 & 2 & 1.56 & 0.44 \\
\hline runoff & 1 & -2.29 & & 1 & -0.38 & & 1 & 1.11 & & 8 & 0.29 & 0.05 \\
\hline \multicolumn{13}{|c|}{ clear-cut site - 1} \\
\hline $\mathrm{Oe} / \mathrm{He}$ & 4 & -2.04 & 0.28 & 4 & -0.37 & 0.06 & & & & 5 & 0.55 & 0.30 \\
\hline $\mathrm{Oa} / \mathrm{Ha}$ & 2 & -1.81 & 0.17 & 3 & -0.37 & 0.06 & & & & 4 & 0.74 & 0.28 \\
\hline $\mathrm{E} / \mathrm{B}$ & 1 & -1.76 & & 1 & -0.41 & & & & & 2 & 1.09 & 0.22 \\
\hline runoff & 1 & -2.05 & & 1 & -0.42 & & & & & 9 & 0.43 & 0.12 \\
\hline \multicolumn{13}{|c|}{ clear-cut site - 2} \\
\hline $\mathrm{Oe} / \mathrm{He}$ & 4 & -2.25 & 0.15 & 4 & -0.41 & 0.06 & & & & 5 & 0.44 & 0.09 \\
\hline $\mathrm{Oa} / \mathrm{Ha}$ & 4 & -1.84 & 0.09 & 4 & -0.41 & 0.07 & & & & 5 & 0.69 & 0.05 \\
\hline $\mathrm{E} / \mathrm{B}$ & 0 & & & 0 & & & & & & 2 & 0.99 & 0.22 \\
\hline runoff & 1 & -2.01 & & 1 & -0.39 & & & & & 9 & 0.30 & 0.05 \\
\hline
\end{tabular}


Table S5: $\mathrm{Hg}$ pool size ( $\mathrm{Hg}$ tot pool) and outflow during sampling period of September 2012 (Outflow) of boreal forest catchments. Data from Kronberg et al. [1] [2].

\begin{tabular}{|c|c|c|c|c|}
\hline Site & $\begin{array}{l}\mathrm{Hg} \text { tot pool } \\
\text { average } \\
\mathrm{g} \mathrm{ha}^{-1}\end{array}$ & $\begin{array}{c}\sigma \\
\mathrm{g} \mathrm{ha}^{-1}\end{array}$ & $\begin{array}{c}\text { Outflow } \\
\text { average } \\
\mathrm{mg} \mathrm{ha}^{-1} \mathrm{month}^{-1}\end{array}$ & $\mathrm{mg} \mathrm{ha}^{-1} \mathrm{month}^{-1}$ \\
\hline \multicolumn{5}{|c|}{ reference site - 1} \\
\hline $\mathrm{Oe} / \mathrm{He}$ & 4.6 & 1.7 & 1.2 & 0.3 \\
\hline $\mathrm{Oa} / \mathrm{Ha}$ & 92.8 & 40.9 & 0.4 & 0.3 \\
\hline total & 97.4 & & 1.6 & 0.13 \\
\hline \multicolumn{5}{|c|}{ reference site - 2} \\
\hline $\mathrm{Oe}$ & 4.0 & 1.7 & 0.9 & 0.30 \\
\hline $\mathrm{Oa}$ & 10.0 & 2.0 & 0.6 & 0.40 \\
\hline total & 14.0 & & 1.5 & 0.11 \\
\hline \multicolumn{5}{|c|}{ clear-cut site - 1} \\
\hline $\mathrm{Oe} / \mathrm{He}$ & 8.8 & 4.4 & 2.7 & 1.20 \\
\hline $\mathrm{Oa} / \mathrm{Ha}$ & 18.8 & 6.3 & 2.2 & 0.30 \\
\hline total & 27.6 & & 4.9 & 0.35 \\
\hline \multicolumn{5}{|c|}{ clear-cut site - 2} \\
\hline $\mathrm{Oe} / \mathrm{He}$ & 8.0 & 2.4 & 2.7 & 1.20 \\
\hline $\mathrm{Oa} / \mathrm{Ha}$ & 56.2 & 23.8 & 2.9 & 1.20 \\
\hline total & 64.2 & & 5.6 & 0.47 \\
\hline
\end{tabular}


1

2

3

4

5

6

7

8

9
Table S6: Results of mixing models: Contributions of different soil horizons to $\mathrm{Hg}$ in runoff based on $\mathrm{Hg}$ isotopes

\begin{tabular}{lll}
\hline Site & $\begin{array}{l}\text { average f } \\
(\%)\end{array}$ & $\begin{array}{c}\sigma \mathrm{f} \\
(\%)\end{array}$ \\
\hline \multicolumn{2}{l}{ reference site - 1 } \\
Oe/He 71 & 17 \\
Oa/Ha & 12 & 11 \\
$\mathrm{E}$ & 16 & 14 \\
\hline reference site - 2 & \\
Oe & 58 & 18 \\
Oa & 20 & 15 \\
$\mathrm{E} / \mathrm{B}$ & 22 & 16 \\
\hline clear-cut site - $\mathbf{1}$ & \\
Oe/He & 55 & 25 \\
Oa/Ha & 25 & 21 \\
$\mathrm{~B}$ & 20 & 16 \\
\hline clear-cut site - 2 & \\
Oe/He & 48 & 22 \\
Oa/Ha & 52 & 9 \\
$\mathrm{E} / \mathrm{B}$ & & \\
\hline
\end{tabular}

Table S7: Validation of enrichment by ultrafiltration: Enrichment factor of $\mathrm{Hg}$ concentration in retentate relative to initial concentration, Percentage of $\mathrm{Hg}$ in retentate relative to total $\mathrm{Hg}$ in $50 \mathrm{~L}$ sample and yield of $\mathrm{Hg}$ in trap solution relative to $\mathrm{Hg}$ in retentate

\begin{tabular}{lccc}
\hline Site & Enrichment factor & $\begin{array}{c}\text { Hg in retentate } \\
(\%)\end{array}$ & $\begin{array}{c}\text { yield } \\
(\%)\end{array}$ \\
\hline reference site - 1 & 19 & 39 & 99 \\
reference site - 2 & 32 & 50 & 76 \\
clearcut site - 1 & 12 & 22 & 100 \\
clearcut site - 2 & 15 & 33 & 70 \\
Lillsele stream & 21 & 44 & 92 \\
\hline
\end{tabular}


Table S8: Model results of fraction of precipitation-derived $\mathrm{Hg}$ relative to litterderived $\mathrm{Hg}$ in runoff samples (see model description in Jiskra et al., 2015 [4]).

\begin{tabular}{lcc}
\hline Site & $\mathrm{f}_{\text {precipitation }}$ & $\mathrm{SD}$ \\
\hline reference site - 1 & 0.15 & 0.05 \\
reference site - 2 & 0.09 & 0.03 \\
clearcut site - 1 & 0.13 & 0.04 \\
clearcut site - 2 & 0.13 & 0.05 \\
Lillsele stream & 0.15 & 0.04 \\
\hline
\end{tabular}




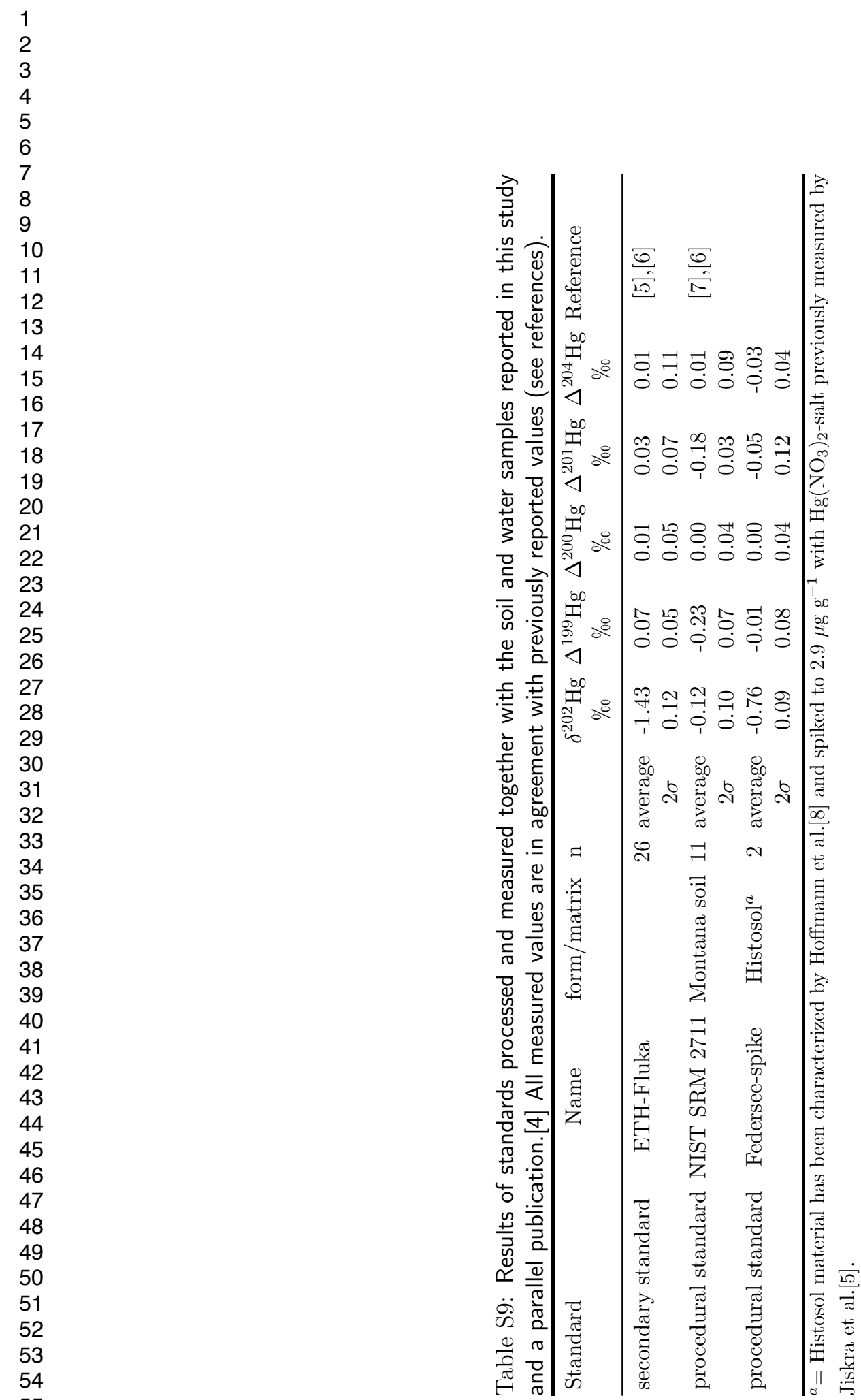

56

57 


\section{References}

[1] R. M. Kronberg, A. Drott, M. Jiskra, J. G. Wiederhold, E. Bjrn, and U. Skyllberg. Forest harvest contribution to Boreal freshwater methyl mercury load. Global Biogeochem. Cycles, 30(6):825-843, 2016.

[2] R. M. Kronberg, M. Jiskra, J. G. Wiederhold, E. Bjorn, and U. Skyllberg. Methyl mercury formation in hillslope soils of boreal forests: The role of forest harvest and anaerobic microbes. Environ Sci Technol, 50(17):917786, 2016.

[3] R.S. Swift. Organic matter characterization, chapter 35, pages 1018-1020. Soil Sci. Soc. Am., Soil Sci. Soc. Am. Book Series: 5, Madison, WI, 1996.

[4] M. Jiskra, J. G. Wiederhold, U. Skyllberg, R.M. Kronberg, I. Hajdas, and R. Kretzschmar. Mercury deposition and re-emission pathways in boreal forest soils investigated with $\mathrm{Hg}$ isotope signatures. Environ. Sci. Technol., 49:7188-96, 2015.

[5] M. Jiskra, J. G. Wiederhold, B. Bourdon, and R. Kretzschmar. Solution speciation controls mercury isotope fractionation of $\mathrm{Hg}$ (II) sorption to goethite. Environ. Sci. Technol., 46(12):6654-6662, 2012.

[6] R. S. Smith, J. G. Wiederhold, A. D. Jew, G. E. Brown Jr, B. Bourdon, and R. Kretzschmar. Small-scale studies of roasted ore waste reveal extreme ranges of stable mercury isotope signatures. Geochim. Cosmochim. Acta, 137(0):1-17, 2014.

[7] N. Estrade, J. Carignan, J. E. Sonke, and O. F. X. Donard. Measuring Hg isotopes in bio-geo-environmental reference materials. Geostand. Geoanal. Res., 34(1):79-93, 2010.

[8] M. Hoffmann, C. Mikutta, and R. Kretzschmar. Bisulfide reaction with natural organic matter enhances arsenite sorption: Insights from X-ray absorption spectroscopy. Environ. Sci. Technol., 46(21):11788-11797, 2012. 